\title{
4+4+4 Ĕgitim Sisteminin Ortaöğretime Yansımalarına İlişkin Öğretmen ve Yönetici Görüşleri ${ }^{1}$
}

DOI: 10.26466/opus.909516

$*$

\author{
Sinan Kayıp ${ }^{*}$ Şefik Kartal ** \\ * Öğretmen, MEB, Tokat Bağlarbaşı İlkokulu, Tokat/Türkiye \\ E-Posta: sinankayip@hotmail.com ORCID: 0000-0003-1306-0398 \\ ** Dr. Öğr. Üyesi, Tokat Gaziosmanpaşa Üniversitesi, Eğitim Fakültesi, Tokat/Türkiye \\ E-Posta: sefik.kartal@gop.edu.tr ORCID: $\quad$ 0000-0002-1448-0987
}

Öz

Bu araştırmanın amacı öğretmen ve yöneticilerin görüşleri alınarak, 4+4+4 eğitim sisteminin ortaöğretime yansımalarına ilişkin paydaş görüşlerini ayrıntılı bir şekilde incelemektir. Araştırma 2017 yılı Şubat-Haziran ayları arasında gerçekleştirilmiştir. Araştırmanın evrenini Tokat ilinde bulunan çeşitli ortaöğretim kurumlarında görev yapan öğretmen ve yöneticiler oluşturmaktadır. 15 öğretmen ve 15 yöneticiden oluşan araştırma örneklemi, amaçlı örneklem yöntemlerinden "maksimum çeşitlilik örneklemesi" ile belirlenmiştir. Bu araştırma nitel bir araştırmadır ve bir nitel araştırma yöntemi olan "görüşme yöntemi" kullanılmıştır. Araştırmada elde edilen verilerin analizinde betimsel analiz kullanılmıştır. Araştırma sonucunda öğretmenler ve yöneticilerden ortä̈ğretimin zorunlu olmasının doğru olduğunu ve yanlış olduğunu ifade edenler olduğu görülmüştür. Geçiş sürecinin hızlı olduğunu, planlamanın yapılmadığın, liselerdeki eğitimin niteliğinin olumsuz etkilendiğini, okulların gerekli fiziki altyap ve teknolojik açıdan yeterli olduğunu, eğitim programlarının güncel olduğunu, zorunlu ortaöğretim sayesinde öğrencilerin kontrol altında tutulduğunu, sanayide ara eleman eksikliği olacağını ve açık lise eğitiminin gerekli olduğunu ifade etmişlerdir. Araştırmada elde edilen sonuçlar doğrultusunda, yeni eğitim sistemine geçilirken geçiş sürecinin çok kısa tutulmaması ve yapılan değişiklikler hakkında öğretmen ve yöneticilere gerekli hizmet içi eğitim ve bilgilendirmelerin yapılması önerilmiştir.

Anahtar Kelimeler: $\quad 4+4+4$ Eğitim sistemi, zorunlu orta öğretim, paydaş görüşleri.

\footnotetext{
${ }^{1}$ Bu çalışma birinci yazarın ikinci yazar danışmanlığında Tokat Gaziosmanpaşa Üniversitesi Eğitim Bilimleri Enstitüsü, Eğitim Programları ve Öğretim Bilim Dalında yazdığı Yüksek Lisans tezinden türetilmiştir.
} 
ISSN:2528-9527

E-ISSN: 2528-9535

YIl Year: 11

Cilt Volume: 18

Sayı Issue: Eğitim Bilimleri Özel Sayısı

Eylül September 2021

\title{
The Views of Teachers and Principals on Reflections of 4+4+4 Education System on Secondary Education
}

*

\begin{abstract}
The aim of this study is to analyse stakeholder views on reflections of $4+4+4$ education system on secondary education in detail by taking the opinions of teachers and principals. The research was carried out between February and June 2017. The population of the research was composed of teachers and principals who work in various high schools in Tokat in Turkey. The research sample, consisting of 15 teachers and 15 principals, was determined by using "maximum variation sampling method", which is one of the purposeful sampling methods. This is a qualitative research and "interview method" was used. Descriptive analysis was used in the analysis of the data obtained in this research. In the research results, it was found out that there were some teachers and principals who stated that the compulsory secondary education is right and there were some who stated that it is wrong. They stated that, the transition process was fast, no planning was done, education quality was affected in negative way in high schools, schools were qualified with necessary physical infrastructure and technological equipments, curricula were up-to-date, students were under control thanks to the compulsory secondary education, there would be lack of intermediate staff in the industry and open high school education was necessary. In line with the results obtained in the research, it was suggested not to keep the transition process too short while transitioning to a new education system and to give the teachers and the principals necessary inservice training and information about the changes.
\end{abstract}

Keywords: 4+4+4 education system, compulsory secondary education, stakeholder views. 


\section{Giriş}

Eğitim bireyde istendik davranış değiştirme süreci olarak tanımlanmaktadır (Senemoğlu, 2011, s.92). Eğitim insan hayatında ve toplum içinde önemli bir faktör olarak yer almaktadır. Tarih boyunca bireylerin ihtiyaçlarına göre toplumlar eğitim sistemlerini yenilemişler veya geliştirmişlerdir. Ülkeler birçok dönemde eğitim sistemlerinde yeniliklere giderek öğretimi daha işlevsel bir hale getirmişlerdir. Kişisel olan öğretim sürecinin, farklı düzeylerdeki okullar aracılığı ile toplumsallaştırılması amaçlanmıştır. Bireyler özel bir şekilde oluşturulan okul ortamı gibi formal bir eğitim sürecine ve ailesi, arkadaşları ve meslektaşları içinde informal eğitim süreçlerine tabi tutulmaktadır (Türer, 2011, s.10). Formal eğitim belirlenmiş bir eğitim programı ile daha önceden belirli yaş gruplarına verilirken informal eğitim ise kişinin okul dışı yaşantısındaki eğitim sürecidir. Bu yüzden formal eğitimin niteliği ve işlevselliği önem taşımaktadır. Çünkü toplumun özelliklerini yansıtan okullarda verilmekte olan eğitim çalışmalarının kalitesi insanlar için çok önemli bir süreçtir. Böylelikle eğitim, kişilerin farklı yönlerde gelişmesini sağlayan bir dönemdir. Bu dönemin doğru bir yöntemle devam etmesi için eğitim faaliyetlerinin planlı bir şekilde değerlendirilmesi gerekmektedir (Demir, Doğan ve Pınar, 2013).

Eğitim sistemi Türer (2009, s.6)' e göre, bağlı olduğu sosyoekonomik sisteme, bu sisteme bağlı (ekonomi, politika, bürokrasi, hukuk, sağlık vb.) diğer alt sistemlere yetişmiş insan gücü yetiştirir. Ĕ̆itim sisteminin genel amacı, yenilik ve değişimlerin denetçisi değil uygulayıcısı olan insanlar yetiştirmektir. Eğitim sistemi problem çözme yeteneğine sahip bireyler yetiştirmelidir. Ayrıca yenilik ile değişimleri özümseyen ve yeni reformlar üreten insan modeli amaçlanmalıdır (Sümbül, 2008, s.448).

Türk Eğitim Sistemi, Türk Milli Eğitiminin genel amaçlarını gerçekleştirmektedir ve bütün eğitim kurumlarının hedefleri temel ilkelere uygun şekilde planlanmaktadır (M.E.T.K., md.3). Türk Eğitim sisteminin genel hedefi, ülke insanının yaşam standartlarını yükseltmek, ekonomik, sosyal ve kültürel kalkınmayı sürekli hale getirmek ve ülke insanının modern dünya ile uyum içinde olmasını sağlamaktır (Ada ve Küçükali, 2009, s.70). Bu temel hedeflerin olmasına karşın Türk Eğitim Sisteminde geçmişten günümüze birtakım sorunlarla karşılaşılmaktadır. Türk Eğitim Sisteminin bütün kademelerinde bazı tartışmalar ve belirsizlikler yaşanmaktadır. 
Bunlara örnek olarak mesleki eğitimde yaşanan nitelik sorunu, yükseköğretime geçiş sürecinde sinav sistemlerinde yaşanan sürekli değişimler, genel eğitim veren liselerde öğrencilerin yerleşmesi ile ilgili yaşanan sıkıntılar, okul türleri ile ilgili sürekli yaşanan değişimler gösterilebilir.

Son yıllarda dünyada eğitim ve okul sistemlerinde yenilikler yapılmaktadır. Bu yeniliklerde yaşam boyu öğrenme modeli örnek alınmaktadır. Eğitim sistemlerinde yapılan değişikliklerde devletin rolü de yeniden planlanmaktadır. Modern dünyadaki eğitim sistemlerinde devletin rolü şöyle açıklanmaktadır: Araştırma ve geliştirme çalışmaları, düzenleyicilik ve yol göstericilik, yüksek şekilde yenilikler üretmek, yerel, milli ve milletlerarası düzeyde karşılaştırmalar yapmaktır (Şişman,2012, s.138).

Şişman (2012, s.162)'n eğitim sisteminin geleceğine ilişkin önerileri şu şekildedir: Eğitimde yapılan yenilikler eğitim sisteminin bütün kademelerini kapsayacak şekilde planlanmalıdır. Eğitim, sosyal, ekonomik, politik alanlarla ve hedefler ile bir bütünlük oluşturmaktadır. Bütün bireylere öğrenme fırsatları sağlamak amaçlanmalı, öğrenciler başarısızlıkları sonucunda sistemin dışına atılmamalıdır. Toplumun eğitime desteğinin artması gerekmektedir. Öğrenciler arasında eşitsizliklere neden olan özel dershanelerin özel öğretim kurumlarına dönüşmeleri gerekmektedir. Mevcut yapılan sınavların yerine daha farklı modern dünya ile uyumlu öğrenci seçme yöntemleri uygulanmalıdır. Türk Eğitim Sisteminin hedeflerinin gelişmiş ülkelerin eğitim seviyeleri düzeyinde olması gerekmektedir.

Güven (2012, s.558)' e göre zorunlu eğitim, bir yurttaşın belli bir yaşa girince eğitime başlamasının zorunlu olduğu, yani devletin vatandaşını devam etmekte zorunlu kıldığ ve devletin belirlemiş olduğu eğitimin süresini kapsamaktadır. Ayrıca zorunlu eğitimin sadece belirli yaştaki çocuklar için değil, temel bilgi ve yeteneklere ihtiyaç duyan her yurttaş için düşünülmüş bir eğitim olduğunu ifade etmektedir. Erginer (2004, s.36) ise zorunlu eğitimi; bireylerin eğitim almak için belirli bir süre ve hedefler belirlenerek devletin yurttaşlarına parasız olarak sunduğu eğitim olarak belirtmiştir. Günümüzde çeşitli ülkelerdeki zorunlu eğitim süresi incelendiğinde bu sürenin en az 4-5 yıl, en çok 12-13 yıl sürmekte olduğu görülmüştür. Zorunlu eğitimin 4 yıl olduğu ülke Sao Tome ve Principe (Afrika); 5 yıl olduğu ülkeler, Ekvator Ginesi, Kolombiya, Bangladeş, İran, Lao De- 
mokratik Halk Cumhuriyeti, Macau, Mynmar, Nepal, Vietnam (çoğunluğu Asya); 12 yıl olduğu ülkeler, Anguilla, St. Kitts ve Nevis (Kuzey Amerika), Belçika, Almanya, Gibraltar (Avrupa), Amerikan Samoası, Tokelau (Antartika); 13 yıl olduğu ülke ise Hollanda'dır (Avrupa). AB ülkelerinde zorunlu eğitim süresi, en az 9 en çok 13 yıldır (Unesco,1999., akt. Erginer, 2004).

Ortaöğretim kademesindeki problemlere Başaran ve Çınkır (2011, s.111)' in çözüm önerileri şu şekildedir: Eğitimde haksız rekabet ve ortaöğretimdeki çeşitlilik kaldırılmalıdır. Ortaöğretimde çeşitlilik yerine, mevcut eğitim programlarını da kapsayan çok amaçlı okullar kurulmalıdır. Mevcut ortaöğretim okulları, bölge okulları olarak eğitime devam etmelidir. Çok amaçlı bölge ortaöğretim okullarının üç ana türlü eğitim programı olması gerekmektedir: (1) yükseköğretime öğrenci hazırlayan program; (2) ortaöğretim düzeyindeki mesleklere ara eleman yetiştirecek program; (3) yaygın eğitim programlarıyla mesleklere ara eleman yetiştirecek program olarak ifade edilmiştir. Ülkelerde eğitim sistemi en çok yeniliklerin yapıldığı konulardan biridir. Eğitim sisteminde yapılan yenilikler, bazen bütün eğitim sistemini kökten değiştirirken bazen ise eğitim sistemini çok değiştirmeden küçük çapta değişiklikler olmaktadır. Türkiye, tarih boyunca Selçuklu, Osmanlı ve Cumhuriyet döneminde sürekli olarak eğitim sisteminde yeniliklere gitmiştir (Ergün, 2003, s.1).

20 Şubat 2012'de "İlköğretim ve Eğitim Kanunu ile Bazı Kanunlarda Değişiklik Yapılmasına Dair Kanun Teklifi" TBMM Başkanlığı'na sunulmuş ve 30 Mart 2012 tarihinde kabul edilmiştir. Bu yasa ile birlikte zorunlu eğitim süresinde de değişikliğe gidilmiştir. Türkiye' de zorunlu eğitim çeşitli reformlardan geçmiş ve sonunda 2012 yılında 12 yıllık zorunlu eğitim sistemine geçilmiştir. 8 yıllık kesintisiz zorunlu eğitim yerine, 12 yıllık zorunlu kademeli eğitim sistemi getirilerek 12 yıllık süre üç kademeye ayrılmıştır. Birinci kademe 4 yıl süreli ilkokul, ikinci kademe 4 yıl süreli ortaokul ve üçüncü kademe 4 yıl süreli lise olarak düzenlenmiştir. Eğitim sisteminde yapılan değişiklikler bütün çocukları, ülkeyi ve ülkenin geleceğini yakından etkilemektedir. Ĕgitim sisteminde yapılan değişiklikler sonrası bazı olumlu ve olumsuz sonuçların ortaya çıktığı düşünülmektedir. Eğitim sistemimiz değiştikten sonra bazı araştırmalar yapılmıştır. Yapılan araştırmaların tamamı, 1 yıl erken ilkokula başlamanın olumlu ve olumsuz yönleri, ilkokul ve ortaokulun ayrılmasında yaşanan problemler 
(bina, öğretmen, vs.) gibi daha çok ilkokul ve ortaokul üzerine yoğunlaşmıştır. Ortaöğretim kademesinin zorunlu olmasına çok az ve yeterli olmayacak şekilde değinilmiştir. Dolayısıyla zorunlu ortaöğretim hakkında yeterli ve açıklayıcı bir değerlendirme mevcut değildir. Bu çalışmada, $4+4+4$ Eğitim Sisteminin ortaöğretime yansımalarına ilişkin paydaş görüşlerinin incelenecek olmasından dolayı bize önemli veriler sunacağı düşünülmektedir.

Bu araştırmada öğretmen ve yöneticilerin görüşleri alınarak, 4+4+4 eğitim sisteminin ortaöğretime yansımalarına ilişkin paydaş görüşlerini ayrıntılı bir şekilde araştırmak amaçlanmıştır. Bu araştırmaya aşağıda belirtilen iki araştırma sorusu yön vermiştir.

1. Öğretmenlerin 4+4+4 Eğitim Sisteminin ortaöğretime yansımalarına ilişkin görüşleri nelerdir?

2. Okul yöneticilerinin $4+4+4$ Eğitim Sisteminin ortaöğretime yans1malarına ilişkin görüşleri nelerdir?

\section{Yöntem}

Bu araştırmada 4+4+4 Eğitim Sisteminin ortaöğretime yansımalarına ilişkin paydaş görüşlerini belirlemek amaçlanmıştır. Bu bağlamda nitel bir araştırma yöntemi olan "görüşme yöntemi" kullanılmıştır. Görüşme yöntemi ile tecrübeler, tutumlar, fikirler, niyetler, yorumlar ve zihinsel algılar ve tepkiler gibi gözlenemeyen soyut kavramlar öğrenilmek amaçlanmaktadır. Burada sorulan sorulara, görüşülen kişinin rahat, doğru ve dürüst bir şekilde cevap vermesini sağlamak görüşmecinin üzerinde durması gereken en önemli görevdir (Yıldırım ve Şimşek, 2013, s.148).

Araştırma 2017 yılı Şubat-Haziran ayları arasında gerçekleştirilmiştir. Araştırmanın evrenini Tokat ilinde yer alan liselerde görev yapan öğretmen ve yöneticiler oluşturmuştur. Araştırmanın örneklemi ise Tokat'ta bulunan farklı okullarda görev yapan 15 öğretmen ve 15 yöneticiden oluşmuştur. Araştırmada görüşü alınan öğretmen ve yöneticiler seçilirken farklı türde ortaöğretim hizmeti veren ve farklı bölgelerde yer alan okullarda görev yapıyor olmalarına dikkat edilmiştir.

Görüşme yapılan öğretmenlerin 13'ü erkek (\%86,6), 2'si ise kadındır $(\% 13,4)$. Öğretmenlerin 5'i meslek lisesinde (\%33,3), 5'i Anadolu lisesinde $(\% 33,3), 3$ 'ü imam hatip lisesinde (\%20), 1'i sosyal bilimler lisesinde 
$(\% 6,6), 1^{\prime} \mathrm{i}$ ise fen lisesinde $(\% 6,6)$ görev yapmaktadır.11-20 yıl arası k1deme sahip 10 öğretmen (\%66,6), 21-30 yıl arası kıdeme sahip 3 öğretmen (\%20), 31-40 yıl arası kıdeme sahip 1 öğretmen $(\% 6,6)$ ve 1-10 yıl arası k1deme sahip 1 öğretmen $(\% 6,6)$ bulunmaktadır.

Görüşme yapılan okul yöneticilerinin tamamı erkektir. Bu yöneticilerden 10'u müdür $(\% 66,6)$ ve 5'i müdür yardımcisı $(\% 33,4)$ olarak görev yapmaktadır. Görüşme yapılacak yöneticilerin belirlenmesinde farklı okul türlerinde görev yapıyor olmalarına dikkat edilmiştir. Yöneticilerin 5'i meslek lisesinde (\%33,4), 3’ü Anadolu lisesinde (\%20), 3'ü imam hatip lisesinde (\%20), 1'i fen lisesinde $(\% 6,6), 1^{\prime} \mathrm{i}$ sosyal bilimler lisesinde $(\% 6,6), 1$ 'i güzel sanatlar lisesinde $(\% 6,6), 1^{\prime} i$ ise spor lisesinde $(\% 6,6)$ görev yapmaktadır. 11-20 yıl arası kıdeme sahip 6 yönetici (\%40), 21-30 yıl arası kıdeme sahip 5 yönetici (\% 33,4), 31-40 yıl arası kıdeme sahip 3 yönetici (\% 20) ve 1-10 yıl arası kıdeme sahip 1 yönetici $(\% 6,6)$ bulunmaktadır.

\section{Verilerin Toplanması ve Analizi}

$\mathrm{Bu}$ araştırmada veri toplama aracı olarak araştırmacılar tarafından öğretmen görüşme formu ve yönetici görüşme formu olmak üzere 2 adet yarı yapılandırılmış görüşme formu hazırlanmıştır. Görüşmelerde araştırmacilar tarafından hazırlanan sorular (En fazla on tane olabilir. En uygunu üç-beştir.) görüşülen kişi ile kısa bir zaman içinde ( üç-beş dakika, ya da azami bir saat) sorulmaktadır ve yanıtlar alınarak kaydedilmektedir (Sönmez ve Alacapinar, 2013, s.108).

Eğitim programları ve öğretim alanında bir öğretim üyesinden uzman görüşü alınarak görüşme formlarının ilk halleri oluşturulmuştur. Bu görüşme formlarının geliştirilmesi aşamasında eğitim programları ve öğretim alanında 3 öğretim üyesi, eğitim yönetimi ve denetimi alanında 1 öğretim üyesi ve eğitim programları ve öğretim alanında 5 doktora öğrencisinden uzman görüşü alınmıştır. Görüşme formunun geliştirilmesi aşamasında bazı uzmanlara e-posta yoluyla ulaşılmış bazıları ile ise bire bir görüşme yapılmıştır. Uzmanlardan sorularla ilgili dil, ifade ve kapsam değişkenleri açısından dönüt vermeleri istenmiş, atılması ve geliştirilmesi gereken soru maddeleri tekrar incelenerek son hali verilmiştir. Öğretmen görüşme formunda 9 adet açık uçlu soru, yönetici görüşme formunda ise 
8 adet açı uçlu soru bulunmaktadır. Ayrıca her iki görüşme formunda bazı soruların altında sonda sorular bulunmaktadır.

Görüşmeler, görüşülen kişilerden izin alınarak ses kayıt cihazına kaydedilmiştir. Görüşmeler ortalama 25 dakika sürmüştür. Görüşmelerde elde edilen ses kayıtları Microsoft Word programına aktarılmıştır.

$\mathrm{Bu}$ araştırmada elde edilen verilerin analizinde betimsel analiz kullanılmıştır. Betimsel analizle genel olarak herhangi bir çalışma hakkında özetleme ve yorumlama yapmak amaçlanmaktadır. Araştırma sonucunda elde edilen veriler, görüşmede sorulan soruların ortaya koyduğu temalara göre yorumlanmıştır (Yıldırım ve Şimşek, 2013, s.256).

Araştırmacılar görüşmede elde edilen verilerin bir bölümünü ayrı ayrı kodlamıştır. Görüşme yapılan her bireyin görüşleri titizlikle incelenmiş ve yorumlanmıştır. Daha sonra görüşmelerden elde edilen veriler ışığında, kodlanmış olan verileri belli kategorilerin altında toplayan alt temalar oluşturulmuştur. Daha sonra araştırmacılar arasında görüş birliği ve görüş ayrıllğı gösteren temalar belirlenmiştir. Temalar ve kodlamalar üzerinde görüş birliğine varıldıktan sonra araştırmacılardan biri, kalan görüşme sonuçlarının analizini yapmıştır. Daha sonra belirlenen temalar ve yapılan kodlamalar eğitim programları ve öğretim alanında bir öğretim üyesi tarafından incelenmiştir. Öğretim üyesinin görüşleri doğrultusunda araştırmacılar tarafindan analizler tekrar yapılmıştır. Araştırmacılar tarafından belirlenen temalar ve yapılan kodlamalar, öğretim üyesi tarafından bir hafta sonra tekrar gözden geçirilmiştir. Araştırmacılar tarafından belirlenen temalar ve yapılan kodlamalar farklı zaman aralıklarında birlikte çalışılarak üç defa gözden geçirilmiştir. Son düzeltmeler yapılarak analizlere en son hali verilmiştir. Bu aşamadan sonra elde edilen veriler belirli olgulara göre tanımlanmış ve düzenlenmiştir.

Nitel analizde aktarılabilirlik (dış geçerlilik) özelliklerinin gerçekleşebilmesi için bazı uygulamalar yapılmaktadır. Bu amaçla aktarılabilirlik özelliğini gerçekleştirmek için görüşmecilerin yantlarından doğrudan alıntılar yapılmıştır (Yıldırım ve Şimşek, 2013, s.304). Doğrudan yapılan alıntıların sonunda alıntının yapıldığı görüşmeciye verilmiş olan numara ve görüşmecinin cinsiyetini belirten harfler köşeli parantez içinde verilmiştir ( Erkek için [E], Kadın için [K] ). 


\section{Bulgular}

Çalışmada yer alan öğretmen ve yöneticiler ile yapılan görüşme kayıtlarının betimsel analizi sonucunda elde edilen bulgular ve yorumlar aşağıda sunulmuştur.

\section{4+4+4 Ĕ̆itim Sisteminin Ortaöğretime Yansımalarına İlişkin Öğretmen} Görüşleri: Öğretmenlerin ortaöğretimin zorunlu eğitim kapsamına alınmasına yönelik genel görüşleri Tablo 1'de verilmiştir.

Tablo 1. Ortaöğretimin Zorunlu Ĕ̆itim Kapsamına Alınması ile İlgili Öğretmen Gö-

\begin{tabular}{|c|c|c|c|c|c|}
\hline Tema & $\mathbf{f}$ & Alt temalar & $\mathbf{f}$ & Öğretmen Görüşleri & $\mathbf{f}$ \\
\hline \multirow{5}{*}{$\begin{array}{l}\text { Genel } \\
\text { görüşler }\end{array}$} & \multirow{5}{*}{17} & Olumlu görüşler & 4 & Zorunlu olması doğru & 4 \\
\hline & & Olumsuz görüşler & 13 & Zorunlu olması yanlış & 7 \\
\hline & & & & Hedefsiz öğrenciler oluştu & 3 \\
\hline & & & & Okumak istemeyenler için olumsuz & 2 \\
\hline & & & & Nitelikli öğrenci azaldı & 1 \\
\hline \multirow{3}{*}{$\begin{array}{l}\text { Planlama } \\
\text { açısından }\end{array}$} & \multirow{3}{*}{20} & Olumlu görüşler & 1 & Planlama yapıldı & 1 \\
\hline & & Olumsuz görüşler & 19 & Planlama yapılmadı & 14 \\
\hline & & & & Kararlar siyasi & 5 \\
\hline \multirow{2}{*}{$\begin{array}{l}\text { Geçiş sü- } \\
\text { reci aç1- } \\
\text { sindan }\end{array}$} & \multirow[t]{2}{*}{9} & Olumsuz görüşler & 9 & Geçiş süreci hızlı oldu & 7 \\
\hline & & & & Öğretmenlerin fikri alınmadı & 2 \\
\hline \multirow{2}{*}{$\begin{array}{l}\text { Hizmet } \\
\text { içi eğitim } \\
\text { açısından }\end{array}$} & \multirow[b]{2}{*}{10} & Olumsuz görüşler & 10 & Eğitim verilmedi & 9 \\
\hline & & & & Öğretmenler istekli değil & 1 \\
\hline
\end{tabular}

“Genel Görüşler" temasının “Olumlu Görüşler" alt temasında "zorunlu olması doğru" görüşü ortaya çıkmıştır. Lise öğretmenlerinin ortaöğretimin zorunlu olması doğru şeklindeki görüşleri şunlardır:

"Ĕ̆itim seviyesinin artması açısından güzel buluyorum." [10-E]

“Genel olarak zorunlu olması güzel."[15-E]

"Genel Görüşler" temasının "Olumsuz Görüşler" alt temasında ise en çok "zorunlu olması yanlış" ve "hedefsiz öğrenciler oluştu" şeklinde görüşler belirtilmiştir. Bu görüşlerden bazıları aşağıda verilmiştir:

"İyi olmadığııı, eğitimin kalitesini düşürdü̈̆̈̈nü düşünüyorum."[7-E]

"Öğrenci zorunlu olarak okula geliyor ve okulda tutmak çok zor." [14-K] 
Yukarıdaki öğretmen ifadelerinde görüldüğü üzere ortaöğretimin zorunlu olmasının doğru olduğunu ve yanlış olduğunu düşünen öğretmenler bulunmaktadır. Doğru olduğunu düşünenler eğitimin kalitesinin artacağını, öğrencileri okulda tutmanın gerektiğini belirtmiştir. Yanlış olduğunu düşünenler ise eğitimin kalitesinin düşeceğini, zorunlu eğitimin yanlış olduğunu, öğrencilerin isteksiz okula geldiklerini ifade etmişlerdir.

"Planlama açısından" temasının "Olumlu Görüşler" alt temasında bir öğretmen "planlama yapıldı" şeklinde görüş belirtmiştir. Bir öğretmenin planlama yapıldı şeklinde görüşü aşağı da verilmiştir:

"Müfredat açısından düzgün planlandı̆̆ııı düşünüyorum. "[6-E]

"Planlama açısından" temasının "Olumsuz Görüşler" alt temasında "planlama yapılmadı" ve "kararlar siyasi" şeklinde görüşlere ulaşılmıştır. Planlamanın yapılmadığına ve alınan kararların siyasi olduğuna ilişkin bazı görüşler şunlardır:

"Bakanlığın bizimle paylaştı̆̆ı 10 yıllık stratejik plan içerisinde yoktu."[4-E]

"Plansız ve düşünülmeden bir geçiş yapıldı."[9-E]

"Geçiş Süreci açısından" temasıyla ilgili olarak herhangi bir olumlu görüş belirtilmemiştir. "Olumsuz Görüşler" alt temasında ise "geçiş süreci hızlı oldu" ve "öğretmenlerin fikri alınmadı" görüşleri bulunmaktadır. Geçiş sürecinin hızlı olduğuna dair ifadelerden bazıları şunlardır:

"Tamamen hızlı bir geçiş süreci oldu."[4-E]

"Öğretmenlerin fikri alınmadı bu kararın siyasi olduğunu düşünüyorum."[7E]

"Hizmetiçi Eğitim açısından" temasıyla ilgili olarak herhangi bir olumlu görüş belirtilmemiştir. "Olumsuz Görüşler" alt temasında ise "eğ $i$ tim verilmedi" ve "öğretmenler istekli değil" görüşleri bulunmaktadır. Hizmetiçi eğitim verilmediğine dair ifadeler aşağıda verilmiştir:

"Hizmetiçi eğitim almadım." [3-E]

"Hizmetiçi eğitim planlanırken branş öğretmenleri unutuluyor." [5-K]

Öğretmenlerin ortaöğretimin zorunlu eğitim kapsamına alınması ile birlikte liselerdeki değişiklikler hakkında görüşleri Tablo 2' de verilmiştir. 
Tablo 2. Ortä̈ğretimin Zorunlu Eğitim Kapsamına Alınması ile Birlikte Liselerdeki Değişiklikler ile İlgili Öğretmen Görüşleri

\begin{tabular}{|c|c|c|c|c|c|}
\hline Tema & $\mathrm{f}$ & Alt temalar & $\mathrm{f}$ & Öğretmen Görüşleri & $\mathrm{f}$ \\
\hline \multirow{8}{*}{$\begin{array}{l}\text { Genel Liseler aç-- } \\
\text { sindan }\end{array}$} & \multirow{8}{*}{18} & \multirow{3}{*}{ Olumlu görüşler } & \multirow{3}{*}{10} & Anadolu Lisesi oldu & 8 \\
\hline & & & & Başarı arttı & 1 \\
\hline & & & & Liseler olumlu etkilendi & 1 \\
\hline & & \multirow{5}{*}{$\begin{array}{l}\text { Olumsuz görüş- } \\
\text { ler }\end{array}$} & \multirow{5}{*}{8} & Genel liseler olumsuz etkilendi & 3 \\
\hline & & & & Davranış problemleri arttı & 2 \\
\hline & & & & Başarı düştü & 1 \\
\hline & & & & Okuma bilmeyen var & 1 \\
\hline & & & & Öğrenci seviyesi düştü & 1 \\
\hline \multirow{13}{*}{$\begin{array}{l}\text { Meslek Liseleri } \\
\text { açısından }\end{array}$} & \multirow{13}{*}{28} & \multirow{4}{*}{ Olumlu görüşler } & \multirow{4}{*}{4} & Meslek öğreniyorlar & 1 \\
\hline & & & & İş yeri açma şansı var & 1 \\
\hline & & & & Meslek lisesi olumlu etkilendi & 1 \\
\hline & & & & Meslek lisesi etkilenmedi & 1 \\
\hline & & \multirow{9}{*}{$\begin{array}{l}\text { Olumsuz görüş- } \\
\text { ler }\end{array}$} & \multirow{9}{*}{24} & Düşük seviyeli öğrenciler geldi & 8 \\
\hline & & & & Meslek lisesi olumsuz etkilendi & 5 \\
\hline & & & & Okuma bilmeyen öğrenciler var & 3 \\
\hline & & & & Eğitim kalitesi düştü & 2 \\
\hline & & & & Kendi alanında ek puan verilmiyor & 2 \\
\hline & & & & Problemli öğrenci çok & 1 \\
\hline & & & & Zorunlu olması yanlış & 1 \\
\hline & & & & Öğrenci sayısı arttı & 1 \\
\hline & & & & Uygulamada eksiklikler var & 1 \\
\hline \multirow{7}{*}{$\begin{array}{l}\text { Özel liseler açısın- } \\
\text { dan }\end{array}$} & \multirow{7}{*}{19} & \multirow{3}{*}{ Olumlu görüşler } & \multirow{3}{*}{13} & Talep arttı & 10 \\
\hline & & & & Bilinçli veliler gönderiyor & 2 \\
\hline & & & & Olumsuz etkilenmedi & 1 \\
\hline & & \multirow{4}{*}{$\begin{array}{l}\text { Olumsuz görüş- } \\
\text { ler }\end{array}$} & \multirow{4}{*}{6} & İyi bir lise kazanamayan yöneldi & 2 \\
\hline & & & & Nitelikli eğitim yok & 2 \\
\hline & & & & $\begin{array}{l}\text { Şişirme notlar olduğu için tercih edi- } \\
\text { liyor }\end{array}$ & 1 \\
\hline & & & & Dershane sistemi var & 1 \\
\hline
\end{tabular}

"Genel Liseler açısından" temasının "Olumlu Görüşler" alt temasında "Anadolu lisesi oldu" ve "başarı arttı" görüşleri ifade edilmiştir. Genel liselerin Anadolu Lisesi olduğuna ilişkin bazı ifadeler şunlardır:

"Genel lise kavramı kalktı. Genel liseler Anadolu adını aldı."[13-E]

"Şimdi bütün liseler Anadolu Lisesi oldu."[15-E]

"Genel Liseler açısından" temasının "Olumsuz Görüşler" alt temasinda en çok"genel liseler olumsuz etkilendi" ve "davranıs problemleri arttı" görüşleri belirtilmiştir. Genel liselerin olumsuz etkilendiğine ve genel liselerde davranış problemlerinin arttığına dair görüşlerden bazıları şunlardir:

"Genel liseler ve meslek liseleri olumsuz etkilendi." [3-E] 
"Davranış problemleri de bir hayli fazla." [4-E]

Yukarıdaki öğretmen ifadelerinde görüldüğ̈̈ üzere genel liselerin Anadolu liselerine dönüştürülmesi olumlu bir gelişme olarak ifade edilmiştir. Olumsuz görüş olarak ise genel liseler ve meslek liselerinin olumsuz etkilendiği ve zorunlu ortaöğretim sonucunda davranış problemlerinin bir hayli fazla olduğu ifade edilmiştir.

"Meslek liseleri açısından" temasının "Olumlu Görüşler" alt temasında "meslek öğreniyorlar", "iş yeri açma şansı var", "meslek liseleri olumlu etkilendi" ve "meslek lisesi etkilenmedi" görüşleri ortaya çıkmıştır. Bu görüşleri belirten ifadeler aşağıda verilmiştir:

"Meslek öğreniyorlar." [2-E]

"İş yeri açma şansı var."[2-E]

"Meslek liselerini olumlu etkilediğini düşünüyorum."[6-E]

"Meslek Liseleri açısından" temasının "Olumsuz Görüşler" alt temasinda en çok "düşük seviyeli öğrenciler geldi", "meslek liseleri olumsuz etkilendi" ve "okuma yazma bilmeyen öğrenciler var" görüşlerine ulaşılmıştır. Olumsuz görüşler alt temasında öğretmenlerin bazı ifadeleri şunlardır:

"Meslek liseleri açısından çok düşük seviyeli öğrenciler geldi."[1-E]

"En çok zarar gören meslek liseleri oldu."[11-E]

“Bep'li öğrencimiz çok, okuma yazma bilmeyen öğrencimiz çok, ..."[2-E]

Yukarıdaki öğretmen ifadelerinden görüldüğü üzere meslek liselerine akademik seviyesi düşük öğrencilerin geldiğini ve mesleki okulların bundan olumsuz etkilendiğini belirtmişlerdir.

"Özel Liseler açısından" temasının "Olumlu Görüşler" alt temasında en çok "talep arttı" görüşü belirtilmiştir. Özel liselerde talep arttığına dair öğretmen görüşlerinden bazıları şunlardır:

“Özel liselere dershaneler kapandiktan sonra talep arttı." [8-E]

"Dershaneler de kapanınca özel liselerin de benzer imkânlar vaat etmesi talebi artirdı." [4-E]

"Özel Liseler açısından" temasının "Olumsuz Görüşler" alt temasında en çok "iyi bir lise kazanamayan yöneldi" ve "nitelikli eğitim yok" görüşlerine ulaşılmıştır.Özel liselere iyi bir lise kazanamayanların yöneldiği ve buralarda nitelikli eğitim olmadığına dair görüşlerden bazıları şunlardır:

"İyi liselere yerleşemeyen çocukları veliler bu okullara gönderdi." [3-E]

"Bu okullarda nitelik olarak kaliteli bir eğitim yok." [1-E] 
Yukarıdaki öğretmen ifadelerinden anlaşıldığı üzere zorunlu ortaöğretim ile birlikte özel liselere talebin arttığı, bunun sebepleri arasında ise iyi bir liseyi kazanamayan öğrencilerin buraları tercih ettiği ve bu okullarda notların biraz daha abartılı verildiği düşüncesinin hâkim olduğu belirtilmiştir. Öğretmenlerin ortaöğretimin zorunlu olması ile birlikte liselerdeki öğrenme ortamları ve öğrenme programları hakkında görüşleri Tablo 3'de verilmiştir.

Tablo 3. Ortaöğretimin Zorunlu Olması ile Birlikte Liselerdeki Öğrenme Ortamları ve Öğretim Programları ile İlgili Öğretmen Görüşleri

\begin{tabular}{|c|c|c|c|c|c|}
\hline Tema & $\mathrm{f}$ & Alt temalar & $\mathrm{f}$ & Öğretmen Görüşleri & $\mathbf{f}$ \\
\hline \multirow{8}{*}{$\begin{array}{l}\text { Öğgrenme ortam- } \\
\text { ları açısından }\end{array}$} & \multirow{8}{*}{35} & \multirow{4}{*}{ Olumlu görüşler } & \multirow{4}{*}{24} & Teknolojik açıdan yeterli & 12 \\
\hline & & & & Fiziki şartlar yeterli & 10 \\
\hline & & & & $\begin{array}{l}\text { Öğrenme ortamı etkilen- } \\
\text { medi }\end{array}$ & 1 \\
\hline & & & & Yeterli & 1 \\
\hline & & \multirow{4}{*}{$\begin{array}{l}\text { Olumsuz görüş- } \\
\text { ler }\end{array}$} & \multirow{4}{*}{11} & Olumsuz etkilendi & 4 \\
\hline & & & & Fiziki şartlar yetersiz & 3 \\
\hline & & & & Öğrenci sayısı fazla & 3 \\
\hline & & & & Derslik ihtiyacı oluştu & 1 \\
\hline \multirow{10}{*}{$\begin{array}{l}\text { Öğretim prog- } \\
\text { ramları açısından }\end{array}$} & \multirow{10}{*}{22} & \multirow{4}{*}{ Olumlu görüşler } & \multirow{4}{*}{12} & Program güncel & 8 \\
\hline & & & & Öğrenci niteliği düşük & 2 \\
\hline & & & & Modüler eğitime geçildi & 1 \\
\hline & & & & $\begin{array}{l}\text { Öğretmenlerin fikri alını- } \\
\text { yor }\end{array}$ & 1 \\
\hline & & \multirow{6}{*}{$\begin{array}{l}\text { Olumsuz görüş- } \\
\text { ler }\end{array}$} & \multirow{6}{*}{10} & $\begin{array}{l}\text { Bütün liselerin müfredatı } \\
\text { aynı }\end{array}$ & 4 \\
\hline & & & & Program güncel değil & 2 \\
\hline & & & & $\begin{array}{l}\text { Programda değişiklik } \\
\text { yok }\end{array}$ & 1 \\
\hline & & & & $\begin{array}{l}\text { Öğretmenlerin fikri alın- } \\
\text { mıyor }\end{array}$ & 1 \\
\hline & & & & Konuların yeri değişiyor & 1 \\
\hline & & & & Program yetersiz & 1 \\
\hline
\end{tabular}

"Öğrenme Ortamları açısından" temasının "Olumlu Görüşler" alt temasında çoğunlukla "teknolojik açıdan yeterli" ve "fiziki şartlar yeterli" şeklinde görüşler belirtilmiştir. Liselerin teknolojik açıdan yeterli olduğuna ve liselerde fiziki şartların yeterli olduğuna dair görüşlerden bazıları şunlardir:

“Okulumuzda Fatih Projesinin tamamı uygulandığı için teknolojik açıdan yeterli." [4-E] 
"Okulumuz gayet yeterli; teknoloji olsun, fiziki olsun." [6-E]

“Öğrenme Ortamları açısından” temasının "Olumsuz Görüşler" alt temasinda "olumsuz etkilendi", "fiziki şartlar yetersiz" ve"öğrenci sayısı fazla" görüşleri ortaya çıkmıştır.Bu görüşlerden bazıları şunlardır:

"Fen liseleri ve bazı başarısı yüksek liseler haricindeki diğer okullar olumsuz etkilendi." [3-E]

"Öğrenci sayımız çok fazla." [8-E]

"Binamı yetersiz, etkinlikler yapacak salonumuz yok, spor salonumuz ve toplantı salonumuz yok." [8-E]

Yukarıdaki öğretmen ifadelerinden anlaşıldığı üzere öğretmenlerin büyük kısmı zorunlu ortaöğretime okulların teknolojik açıdan ve fiziki şartlar açısından hazır olduğunu fakat bazı eski binalarda derslik için uygun olmayan yerlerin dersliklere dönüştürüldüğünü, oyun alanlarının ve spor salonlarının yetersiz olduğunu ve bazı problemlerin yaşandığını belirtmişlerdir.

"Öğretim Programları açısından" temasının "Olumlu Görüşler" alt temasında en çok "program güncel" görüşü ifade edilmiştir. Öğretim programlarının güncel olduğuna dair bazı görüşler şunlardır:

"2-3 senede bir güncelleme yapılıyor." [5-E]

"2-3 kere yenilendi ve şu an yeni bir program sunuldu." [7-E]

"Sürekli güncelleme yapılıyor." [12-E]

"Öğretim Programları açısından" temasının "Olumsuz Görüşler" alt temasında en çok "bütün liselerin müfredatı aynı" ve "program güncel değ il" görüşleri ifade edilmiştir. Bu görüşlerden bazıları şunlardır:

"Aynı müfredatı fen liseleri de meslek liseleri de kullanıyor. Programların ayrilmasi gerekiyor." [12-E]

"Eğitimde reform istiyorsak öğretim programımız güncel olmalı. Bunlarda belirli uzmanlar tarafindan değişiklikler olması şarttır. Pek bu önemsenmiyor. Programlar yeniden revize edilmeli." [15-E]

Yukarıdaki öğretmen ifadelerinde görüldüğ̈̈ gibi öğretmenler programların güncel olduğunu düşünmekte fakat lise 1. sınıflarda fen lisesi ve meslek lisesi gibi okulların aynı ders içeriklerini görmesini yanlış bulmaktadırlar. Öğretmenlerin ortaöğretimin zorunlu olması ile birlikte ortaöğretime geçiş sistemi ve mesleki rehberlik hakkında görüşleri Tablo 4’te verilmiştir. 
Tablo 4. Ortaöğretimin Zorunlu Olması ile Birlikte Ortaöğretime Geçiş Sistemi ve Mesleki Rehberlik ile İlgili Öğretmen Görüşleri

\begin{tabular}{|c|c|c|c|c|c|}
\hline Tema & $\mathrm{f}$ & Alt temalar & $\mathrm{f}$ & Öğretmen Görüşleri & $\mathrm{f}$ \\
\hline \multirow{10}{*}{$\begin{array}{l}\text { Ortaöğretime geçiş sis- } \\
\text { temi açısından }\end{array}$} & \multirow{10}{*}{24} & Olumlu görüşler & 2 & TEOG sınavı doğru & 2 \\
\hline & & Olumsuz görüşler & 3 & TEOG seçici değil & 3 \\
\hline & & \multirow{8}{*}{ Öneriler } & \multirow{8}{*}{19} & Sinav olmalı & 12 \\
\hline & & & & $\begin{array}{l}\text { Her okulun sınav } \\
\text { yapması yanlış olur }\end{array}$ & 1 \\
\hline & & & & $\begin{array}{l}\text { Not ortalaması etkili } \\
\text { olmalı }\end{array}$ & 1 \\
\hline & & & & $\begin{array}{l}\text { Sinav olmazsa motive } \\
\text { olunamaz }\end{array}$ & 1 \\
\hline & & & & $\begin{array}{l}\text { Zorunlu eğitim olmaz } \\
\text { ise sınav olmayabilir }\end{array}$ & 1 \\
\hline & & & & $\begin{array}{l}\text { Becerisi olanlar mes- } \\
\text { lek lisesine gitmeli }\end{array}$ & 1 \\
\hline & & & & $\begin{array}{l}\text { Fen lisesi sinavla ol- } \\
\text { malı }\end{array}$ & 1 \\
\hline & & & & $\begin{array}{l}\text { Genel liseler sinavsız } \\
\text { olsun }\end{array}$ & 1 \\
\hline \multirow{7}{*}{$\begin{array}{l}\text { Mesleki rehberlik açısın- } \\
\text { dan }\end{array}$} & \multirow{7}{*}{24} & \multirow{7}{*}{ Olumlu görüşler } & \multirow{7}{*}{24} & $\begin{array}{l}\text { Rehber öğretmenler } \\
\text { bilgilendiriyor }\end{array}$ & 8 \\
\hline & & & & $\begin{array}{l}\text { Meslek grupları ko- } \\
\text { nuşma yapıyor }\end{array}$ & 6 \\
\hline & & & & $\begin{array}{l}\text { Bölüm bilgilendirmesi } \\
\text { yapılıyor }\end{array}$ & 4 \\
\hline & & & & $\begin{array}{l}\text { Kariyer günleri yapılı- } \\
\text { yor }\end{array}$ & 3 \\
\hline & & & & $\begin{array}{l}\text { Puan türleri bilgilen- } \\
\text { dirmesi yapıllyor }\end{array}$ & 1 \\
\hline & & & & $\begin{array}{l}\text { Üniversite gezileri ya- } \\
\text { piliyor }\end{array}$ & 1 \\
\hline & & & & Koçluk sistemi var & 1 \\
\hline
\end{tabular}

"Ortaöğretime Geçiş Sistemi açısından" temasının "Olumlu Görüşler" alt temasında "TEOG sınavı yapılması doğru" görüşü ifade edilmiştir. TEOG sınavının yapılmasının doğru olduğuna dair görüşler şunlardır:

"TEOG sinavin olumlu buluyorum. Not ortalamasının liseye girişte etkili olması güzel. Çocuklarm ilgisini, öğretmenlerin konsantrasyonunu yüksek tutuyor. Öğretmende kendini değerlendiriyor." [5-E]

"TEOG iyi bir sistem." [8-E]

"Ortaöğretime Geçiş Sistemi açısından" temasının "Olumsuz Görüşler" alt temasında "TEOG seçici değil görüşü" ifade edilmiştir. TEOG sınavının seçici olmadığına dair görüşlerden bazıları şunlardır: 
"Hiç seçici bir sinav olduğunu düşünmüyorum. Sorular çok kolay. Türkiye genelinde binlerce tam yapan öğrenci var. TEOG olmalı ama içerik zenginleşmeli." [3-E]

"TEOG sinavı seçici bir sinav değil. Çok kısıtlı bir alandan soru soruluyor. TEOG ile gelen öğrenciler ile SBS ile gelen öğrenciler arasında bariz fark görüyorum." [10-E]

Yukarıdaki öğretmen ifadelerinde görüldüğü üzere ortaöğretime geçişte merkezi sınavın olması gerektiği belirtilmiştir.

"Mesleki Rehberlik açısından" temasının "Olumlu Görüşler" alt temasinda en çok "rehber öğretmenler bilgilendiriyor" ve "meslek grupları konuşma yapıyor" görüşleri bulunmaktadır. Bu görüşlerden bazıları şunlardır:

"Rehberlik servisi birebir ve toplu görüşmeler yapıyor." [13-E]

"Kariyer günleri yapılıyor. Değişik meslek gruplarından insanlar getirtiliyor." [5-E]

Ortaöğretimin zorunlu eğitim kapsamına alınması aşamasında eğitimin niteliğine ilişkin öğretmen görüşleri Tablo 5'de verilmiştir.

"Eğitimin Niteliği açısından" teması incelendiğinde herhangi bir olumlu görüş alınmamıştır. "Olumsuz Görüşler" alt temasında ise "eğitimin kalitesi olumsuz etkilendi" ve "davranıs problemleri arttı" görüşlerine ulaşılmıştır. Ulaşılan görüşlerden bazıları şunlardır:

"Herkes mezun olmak zorunda olunca, kalite düştü." [5-E]

"Kalitenin çok düştü̈̆̈̈̈nü görüyorum. Eskiden sorduğum soruları soramıyorum." [7-E]

“Öğrenciler süzülerek gelse daha iyi olacak. Böyle olmadığı için başarısız öğrenciler ortamı olumsuz etkiliyor. Başarısız öğrenci sayısı arttı ve davranış problemleri de arttı." [8-E] 
Tablo 5. Ortaöğretimin Zorunlu Ĕ̆itim Kapsamına Alınması Sonucunda Eğitimin Niteliği ile İlgili Öğretmen Görüş̧leri

\begin{tabular}{|c|c|c|c|c|c|}
\hline Tema & f & Alt temalar & $\mathbf{f}$ & Öğretmen Görüşleri & f \\
\hline \multirow{5}{*}{$\begin{array}{l}\text { Eğitimin niteliği } \\
\text { açısından }\end{array}$} & \multirow{5}{*}{16} & \multirow{5}{*}{$\begin{array}{l}\text { Olumsuz gö- } \\
\text { rüşler }\end{array}$} & \multirow{5}{*}{16} & Eğitimin kalitesi olumsuz etkilendi & 11 \\
\hline & & & & Davranış problemleri arttı & 2 \\
\hline & & & & Ders saatleri fazla & 1 \\
\hline & & & & Liseler arasında seviye farkı arttı & 1 \\
\hline & & & & Başarısız öğrenci sayısı arttı & 1 \\
\hline \multirow{2}{*}{$\begin{array}{l}\text { Ortaokuldaki aka- } \\
\text { demik başarının li- } \\
\text { seye yansıması açı- } \\
\text { sından }\end{array}$} & \multirow[b]{2}{*}{13} & \multirow[b]{2}{*}{$\begin{array}{l}\text { Olumsuz gö- } \\
\text { rüşler }\end{array}$} & \multirow[b]{2}{*}{13} & Notlar abartılı & 12 \\
\hline & & & & Özel okullarda notlar abartılı & 1 \\
\hline \multirow{6}{*}{$\begin{array}{l}\text { Öğrencilerin lise- } \\
\text { deki temel dersler- } \\
\text { deki durumu açı- } \\
\text { sından }\end{array}$} & \multirow{6}{*}{17} & Olumlu gö- & 2 & Temel derslerde yeterli & 1 \\
\hline & & rüşler & & Yüksek puanlı okulda yeterli & 1 \\
\hline & & \multirow{4}{*}{$\begin{array}{l}\text { Olumsuz gö- } \\
\text { rüşler }\end{array}$} & \multirow{4}{*}{15} & Temel derslerde yetersiz & 11 \\
\hline & & & & Yorumlama özelliği yok & 2 \\
\hline & & & & Sayısal derslerde yetersiz & 1 \\
\hline & & & & Düşük puanlı okullarda yetersiz & 1 \\
\hline
\end{tabular}

"Ortaokuldaki akademik başarının liseye yansıması açısından" temasinda herhangi bir olumlu görüş alınmamıştır. "Olumsuz Görüşler" alt temasında en çok "notlar abartılı" görüşü ifade edilmiştir. Ortaokulda öğrenci notlarının abartılı olduğuna dair görüşlerden bazıları şunlardır:

"Puanların tamamen şişirme olduğunu düşünüyorum. Bunu özel okullar daha fazla yapiyor." [1-E]

"Gerçeği yansitmıyor. Soruyorsun matematiğinin 5 olduğunu söylüyor. 101'i 11'e bölemiyor." [7-E]

“Öğrencilerin lisedeki temel derslerdeki durumu açısından" temasının "Olumlu Görüşler" alt temasında "temel derslerde yeterli" ve "yüksek puanl okullarda yeterli" görüşleri ortaya çıkmıştır. Bu görüşlerin bazıları şunlardir:

"Başarnlı okullara gelen çocuklar yeterli. Diğer okullardaki çocuklar yetersiz." [13-E]

“Temel derslerde yeterli."[14-E]

"Öğrencilerin lisedeki temel derslerdeki durumu açısından" temasının "Olumsuz Görüşler" alt temasında en çok "temel derslerde yetersiz" görüşünü belirtmişlerdir.

Liselerde öğrencilerin temel derslerde yeterli olmadığına dair görüşlerden bazıları şunlardır:

"Genel olarak yetersiz görüyorum. Özellikle sayısal derslerde bocalıyorlar." [6-E] 
"Temel derslerde yetersiz görüyorum. Çocuklar ezberci bir şekilde okula geliyorlar. Yorumlama kapasiteleri çok az." [8-E]

Yukarıdaki ifadelerde görüldüğ̈̈ gibi özellikle ortaöğretimin zorunlu olması ile birlikte özellikle düşük seviyedeki öğrencilerin liseye devam etme zorunluluğu, ortaokulda ve liselerde notların abartılı olması ve bu yüzden öğrencilerin liseye başladıklarında temel derslerde yetersiz kalmaları neticesinde eğitimin niteliğinin olumsuz etkilendiği düşünülmektedir. Ortaöğretimin zorunlu eğitim kapsamına alınması ile beraber Türk eğitim sistemindeki değişikliklere ilişkin öğretmen görüşleri Tablo 6’ da verilmiştir.

Tablo 6. Ortaöğretimin Zorunlu Eğitim Kapsamına Alınması ile Beraber Türk Eğitim Sistemindeki Değişiklikler ile İlgili Öğretmen Görüşleri

\begin{tabular}{|c|c|c|c|c|c|}
\hline Tema & f & Alt temalar & $\mathbf{f}$ & Öğretmen Görüşleri & $\mathbf{f}$ \\
\hline \multirow{5}{*}{$\begin{array}{l}\text { Eğitim Sistemi } \\
\text { açısından }\end{array}$} & \multirow{5}{*}{24} & \multirow{5}{*}{$\begin{array}{l}\text { Olumsuz gö- } \\
\text { rüşler }\end{array}$} & \multirow{5}{*}{24} & Mesleki eğitimde değişiklik yok & 7 \\
\hline & & & & Bütün liseler Anadolu Lisesi oldu & 6 \\
\hline & & & & Değişim olmadı & 6 \\
\hline & & & & Sınıf geçme kolaylaştı & 3 \\
\hline & & & & Nitelik olarak değişim yok & 2 \\
\hline
\end{tabular}

"Eğitim Sistemi açısından" temasında herhangi bir olumlu görüş bulunmamaktadır. "Olumsuz Görüşler" alt temasında en çok "mesleki e ğ $i$ timde değişiklik yok", "bütün liseler Anadolu lisesi oldu" ve "değişim olmadı" görüşleri ifade edilmiştir. Bu görüşlerden bazıları aşağıda verilmiştir.

"Mesleki eğitimde bir değişim olmadı." [15-E]

"Reform yapıldiğını düşünmüyorum. Sadece mecburi oldu. Hiçbir yenilik yok. Okullarm ismi değişti sadece." [8-E]

"Eğitim sistemimizde herhangi bir değişiklik olmadı. Sadece istatistikleri düzeltme adına yapuldı." [3-E]

Yukarıdaki öğretmen ifadelerinde görüldüğü üzere zorunlu ortaöğretim ile birlikte nitelikli bir değişimin olmadığı belirtilmektedir. Ayrıca mesleki eğitimde hiçbir değişikliğin olmadı̆̆ı genel liselerde ise sadece okul isimlerinde değişiklikler yaşandığı ifade edilmiştir.

Ortaöğretimin zorunlu eğitim kapsamına alınmasının sağladığı gelişmeler hakkında öğretmen görüşleri Tablo 7'de verilmiştir. 
Tablo 7. Ortaöğretimin Zorunlu Ĕ̆itim Kapsamına Alınmasının Sağladı̆̆ı Gelişmeler ile İlgili Öğretmen Görüssleri

\begin{tabular}{|c|c|c|c|c|c|}
\hline Tema & $\mathrm{f}$ & Alt temalar & $\mathrm{f}$ & Öğretmen Görüşleri & $\mathbf{f}$ \\
\hline \multirow{20}{*}{$\begin{array}{l}\text { Ortaöğretimin } \\
\text { zorunlu eğitim } \\
\text { kapsamına alın- } \\
\text { masının sağla- } \\
\text { dığı gelişmeler }\end{array}$} & \multirow{20}{*}{37} & \multirow{8}{*}{$\begin{array}{l}\text { Olumlu görüş- } \\
\text { ler }\end{array}$} & \multirow{8}{*}{11} & Çocuklar kontrol altında oluyor & 3 \\
\hline & & & & Kötü alışkanlıklardan korunuyor & 2 \\
\hline & & & & Kırsalda eğitime katılım arttı & 1 \\
\hline & & & & Sosyalleşme arttı & 1 \\
\hline & & & & Gençler eğitimin içinde kalıyor & 1 \\
\hline & & & & Lise mezunu arttı & 1 \\
\hline & & & & Okuma fırsatı olmayanlar için olumlu & 1 \\
\hline & & & & Fırsat eşitliği sağladı & 1 \\
\hline & & \multirow{12}{*}{$\begin{array}{l}\text { Olumsuz gö- } \\
\text { rüşler }\end{array}$} & \multirow{12}{*}{26} & Ara eleman eksikliği oldu & 7 \\
\hline & & & & Olumlu yönü yok & 5 \\
\hline & & & & İşsizlik oranı arttı & 3 \\
\hline & & & & Öğrenci profili düştü. & 2 \\
\hline & & & & Mezunlarda mesleki beceri olmayacak & 2 \\
\hline & & & & Öğrencinin hayata atılması gecikiyor & 1 \\
\hline & & & & Sanayi esnafı etkilendi & 1 \\
\hline & & & & İş gücü kaybı oldu & 1 \\
\hline & & & & Ekonomik maliyet getirdi & 1 \\
\hline & & & & Olumsuz davranışlara neden oldu & 1 \\
\hline & & & & Öğrencilerin aynı sınava girmesi adil değil & 1 \\
\hline & & & & Ders yükü arttı & 1 \\
\hline
\end{tabular}

“Ortaöğretimin zorunlu eğitim kapsamına alınmasının sağladığı gelişmeler" temasının "Olumlu Görüşler" alt temasında en çok "çocuklar kontrol altında oluyor" ve "öğrenciler kötü alışkanlıklardan korunuyor" görüşlerine ulaşılmıştır. Bu görüşlerden bazıları şunlardır: E]

"Çocukları okulda güvende tutuyorsun akşama kadar güvenli bir yerde." [14-

"Çocukları okulda kontrol altında tutarak suçtan ve kötü alışkanlıklardan korunabilir." [3-E]

"Ortaöğretimin zorunlu eğitim kapsamına alınmasının sağladığı gelişmeler" temasının "Olumsuz Görüşler" alt temasında en çok "ara eleman eksikliği oldu" ve "olumlu yönü yok" görüşleri yapılmıştır. Bu görüşlerden bazıları aşağıda verilmiştir:

"Ara eleman eksikliği oluştu." [3-E]

"Liseyi bitirdikten sonra mesleki bir becerileri olmayacak." [5-E]

"Hiç olumlu bir tarafı yok." [12-E]

Yukarıdaki öğretmen ifadelerinden anlaşıldığı üzere ortaöğretimin zorunlu olması ile çocukların okulda kontrol altında olacağı ve öğrencilerin okula devam ederek kötü alışkanlıklardan korunacağı şeklinde görüşler 
bulunmaktadır. Fakat özellikle mesleki alanlarda ara eleman eksikliği oluşacağ1 ve bir meslek öğrenemeyen gençlerin işsizlik sorunu yaşayacağ şeklinde görüş belirtenler bulunmaktadır.

Açık lise eğitimi hakkında öğretmen görüşleri Tablo 8' de verilmiştir.

Tablo 8. Açık Lise Eğitimi ile Illgili Öğretmen Görüşleri

\begin{tabular}{|c|c|c|c|c|c|}
\hline Tema & $\mathbf{f}$ & Alt temalar & $\mathrm{f}$ & Öğretmen Görüşleri & $\mathrm{f}$ \\
\hline \multirow{17}{*}{$\begin{array}{l}\text { Açık lise } \\
\text { eğitimi } \\
\text { hakkında } \\
\text { görüşler }\end{array}$} & \multirow{17}{*}{46} & \multirow{10}{*}{$\begin{array}{l}\text { Olumlu gö- } \\
\text { rüşler }\end{array}$} & \multirow{10}{*}{34} & Gerekli & 11 \\
\hline & & & & Örgün eğitime devamı engellemez & 5 \\
\hline & & & & Okumayanlar için 2. fırsat & 5 \\
\hline & & & & Hem çalışıp hem okumak mümkün alternatif olabi- & 4 \\
\hline & & & & Eğitimde kalite artar & 2 \\
\hline & & & & Lise mezunu sayısı artar & 2 \\
\hline & & & & Sınıf ortamından bağımsız & 2 \\
\hline & & & & Öğrenci gayretine bağlı & 1 \\
\hline & & & & Mesleki eğitimde faydalı & 1 \\
\hline & & & & Ara eleman yetişir & 1 \\
\hline & & \multirow{7}{*}{$\begin{array}{l}\text { Olumsuz gö- } \\
\text { rüşler }\end{array}$} & \multirow{7}{*}{12} & Örgün eğitime devamı engeller & 6 \\
\hline & & & & Gereksiz & 1 \\
\hline & & & & İnsan ilişkisi yok & 1 \\
\hline & & & & Çocuklar dışlanıyor & 1 \\
\hline & & & & Örgün eğitimle fark çok & 1 \\
\hline & & & & Kontrol sıkıntısı var & 1 \\
\hline & & & & Akşam çalışacak personel yok & 1 \\
\hline
\end{tabular}

"Açık Lise Eğitimi hakkında görüşler" temasının "Olumlu Görüşler" alt temasında en çok "gerekli", "örgün eğitime devamı engellemez" ve "okumayanlar için 2. firsat" görüşleri bulunmaktadır. Bu görüşlerden bazıları şunlardir:

"Okuyamayan adamı çok fazla okulun içinde tutmanın bir anlamı yok. Doğru bir uygulama." [7-E]

"Örgün eğitime devamı engellemez." [8-E]

"Engellemez. Kırsal kesimde olabilir." [14-E]

"Zamanında şans verilmeyen kız çocukları ve bir şekilde okuma firsatı bulamayan insanlar için 2. firsat olarak görüyorum." [5-E]

"Açık Lise Eğitimi hakkında görüşler" temasının "Olumsuz Görüşler" alt temasında "en çok örgün eğitime devamı engeller" görüşü bulunmaktadır. Bu görüşlerden bazıları aşağıda verilmiştir:

"Engeller. Hem çalışıp hem okurum diyenler için engeller." [1-E]

"Çocuklarm liseye devam etmemelerini özendirebilir." [5-E]

"Kız çocuklarında kullanabilirler. Tedbirleri almak gerekir." [10-E] 
Yukarıdaki ifadelerde görüldüğü gibi öğretmenlerin büyük kısmı açık lise eğitiminin gerekli olduğunu düşünmektedir. Zamanında okuyamayanlar için bir fırsat olabileceği fakat kırsal kesimde özellikle kız öğrenciler için ise örgün eğitimi engelleyebileceği şeklinde görüşler bulunmaktadir.

Lise öğretmenlerine ortaöğretim sisteminde değişiklik önerileri sorulmuştur. Öğretmenlerin önerileri şunlardır:

"Daha çok sosyal aktivitelere yer verilmeli."

"Öğrenciler sanat ve spor açısından desteklenmeli."

"Düşük profilli öğrenciler çıraklık okuluna gitmeli."

"Ders saati azaltılmalı."

"Mesleki eğitime önem verilmeli."

"Ders geçme sistemi düzenlenmeli."

"Meslek lisesi öğrencisi desteklenmeli."

"Liseye geçiş sınavı nitelikli olmalı."

"Lise türlerinde eğitim müfredatını değiştirirdim."

"Üniversite sinavında mesleki öğrencilere mesleki sorular sorulmalı."

"Üniversite sınavın kaldırırdım."

"Anadolu Lisesi ve Imam Hatip Lisesi sayısinı azaltırdım."

"Meslek liseleri mezunların sinavsız atardım."

"Meslek liselerin ekipmanlarn tam olmall."

"Eğitimde çeşitlilik olması gerekir."

"Öğretmenler okul müdürünü seçmeli."

"Öğrenci yönlendirme sistemi değişmeli."

\section{4+4+4 Eğitim Sisteminin Ortaöğretime Yansımalarına İlişkin Yönetici Görüşleri}

Ortaöğretimin zorunlu eğitim kapsamına alınmasına ilişkin yönetici görüşleri Tablo 9'da verilmiştir. 
Tablo 9. Ortaöğretimin Zorunlu Eğitim Kapsamına Alınması ile İlgili Okul Yöneticilerinin Görüşleri

\begin{tabular}{|c|c|c|c|c|c|}
\hline Tema & $\mathrm{f}$ & Alt temalar & $\mathbf{f}$ & Yönetici Görüşleri & $\mathrm{f}$ \\
\hline \multirow{14}{*}{$\begin{array}{l}\text { Genel gö- } \\
\text { rüşler }\end{array}$} & \multirow{14}{*}{33} & \multirow{8}{*}{$\begin{array}{l}\text { Olumlu görüş- } \\
\text { ler }\end{array}$} & \multirow{8}{*}{18} & Zorunlu olması olumlu & 8 \\
\hline & & & & Okullaşmanın düşük olduğu yerlerde faydalı & 2 \\
\hline & & & & $\begin{array}{l}\text { Kızların erken evlendirilmesi ve okula gönde- } \\
\text { rilmemelerine çözüm olur }\end{array}$ & 2 \\
\hline & & & & Çağdaş seviyelere ulaşmak için gerekli & 2 \\
\hline & & & & Daha iyi eğitim için seviyesi için gerekli & 1 \\
\hline & & & & $\begin{array}{l}\text { Kaliteyi artırmak için üniversite mezunu art- } \\
\text { malı }\end{array}$ & 1 \\
\hline & & & & Diğer ülkelerle yarışmak için gerekli & 1 \\
\hline & & & & Zorunlu lise eğitimi olmalı & 1 \\
\hline & & \multirow{6}{*}{$\begin{array}{l}\text { Olumsuz görüş- } \\
\text { ler }\end{array}$} & \multirow{6}{*}{15} & Sanayide ara eleman eksikliği oluştu & 5 \\
\hline & & & & Zorunlu olması doğru değil & 4 \\
\hline & & & & Lise mezunu işsiz sayısı çok fazla oldu & 2 \\
\hline & & & & Vasıfsız mezunlar oluyor & 2 \\
\hline & & & & Küçük yerlerde staj alanları yok & 1 \\
\hline & & & & $\begin{array}{l}\text { Başarısız ve kaynaştırma öğrencileri akade- } \\
\text { mik eğitim içinde yer aldı }\end{array}$ & 1 \\
\hline \multirow{6}{*}{$\begin{array}{l}\text { Planlama } \\
\text { açısından }\end{array}$} & \multirow{6}{*}{12} & \multirow{2}{*}{$\begin{array}{l}\text { Olumlu görüş- } \\
\text { ler }\end{array}$} & \multirow[t]{2}{*}{3} & Planlama yapıldı & 2 \\
\hline & & & & Kalkınma planlarında vardı & 1 \\
\hline & & \multirow{4}{*}{$\begin{array}{l}\text { Olumsuz görüş- } \\
\text { ler }\end{array}$} & \multirow{4}{*}{9} & Planlama aceleyle yapıldı & 4 \\
\hline & & & & Planlama yapılmadı & 2 \\
\hline & & & & $\begin{array}{l}\text { Bazı liseleri ön plana çıkarmak amacı plan- } \\
\text { landı }\end{array}$ & 2 \\
\hline & & & & Eğitimcilerin görüşü alınmadı & 1 \\
\hline \multirow{5}{*}{$\begin{array}{l}\text { Geçiş sü- } \\
\text { reci açı- } \\
\text { sindan }\end{array}$} & \multirow{5}{*}{26} & \multirow{5}{*}{$\begin{array}{l}\text { Olumsuz görüş- } \\
\text { ler }\end{array}$} & \multirow{5}{*}{26} & Çok hızlı oldu & 8 \\
\hline & & & & Aksaklıklar yaşandı & 8 \\
\hline & & & & Alt yapı hazırlanmadı & 4 \\
\hline & & & & Bazı branşlarda öğretmen eksikliği oldu & 3 \\
\hline & & & & Kademeli olarak yapılsayd $d_{1}$ sorunlar olmazd 1 & 3 \\
\hline \multirow{3}{*}{$\begin{array}{l}\text { Hizmet } \\
\text { içi eğitim } \\
\text { açısından }\end{array}$} & \multirow{3}{*}{17} & Olumlu görüş- & 5 & Hizmet içi eğitim aldım & 4 \\
\hline & & ler & & Kendimiz inceleyerek öğrendik & 1 \\
\hline & & $\begin{array}{l}\text { Olumsuz görüş- } \\
\text { ler }\end{array}$ & 12 & Eğitim verilmedi & 12 \\
\hline
\end{tabular}

"Genel Görüşler açısından" temasının "Olumlu Görüşler" alt temasinda en çok "zorunlu olması olumlu" görüşü ortaya çıkmıştır. Bu görüşlerden bazıları aşağıda verilmiştir:

"Daha iyi bir eğitim seviyesine yükselmek için olumlu buluyorum." [1-E]

"Liselerin zorunlu olması ve herkesi eğitimin içine almak doğru."[11-E]

"Genel Görüşler açısından" temasının "Olumsuz Görüşler" alt temasinda ise en çok "sanayide ara eleman eksikliği oluştu" ve "zorunlu olması doğru değil" şeklinde görüşler belirtilmiştir. Bu görüşlerden bazıları aşağıda verilmiştir:

"5 yil sonra oto tamircisi, elektrikçi kalmayacak." [3-E] 
"Ara eleman ihmal ediliyor. Sanayide artık çırak bulunamıyor. Ara eleman yetiştirmek için formül bulmamız gerekir." [9-E]

"Liselerin zorunlu olmasina sicak bakmıyorum." [15-E]

Yukarıdaki ifadelerde görüldüğü gibi yöneticilerin büyük kısmı ortaöğretimin zorunlu olmasını olumlu bir adım olarak belirtmektedirler. Okullaşma açısından, kız çocukları açısından ve çağdaş seviyelere erişim anlamında olumlu bulduklarını ifade eden görüşlerde bulunmaktadır. Bununla birlikte sanayide ara eleman eksikliği oluştuğunu ve zorunlu olmasını olumlu bulmadıklarını belirtenler de bulunmaktadır.

"Planlama açısından" temasının "Olumlu Görüşler" alt temasında en çok "planlama yapıldı" görüşü belirtilmiştir. Öğretmenlerin planlama yapıldığına ilişkin görüşleri aşağıda verilmiştir:

"İyi planlanmıştı." [1-E]

"Planlandığııı düşünüyorum." [15-E]

"Planlama açısından" temasının "Olumsuz Görüşler" alt temasinda" planlama aceleyle yapıldı", "planlama yapılmadı" ve "bazı liseleri ön plana çıkarmak amacı planlandı" şeklinde görüşlere ulaşılmıştır. Bu görüşlerden bazıları şunlardır:

"Planlama biraz aceleye geldi." [7-E]

"Planlama açısından bakacak olursak altyapı hazırlanmadan zorunlu lise eğitimine geçildiğini düşünüyorum." [4-E]

"Zorunlu lise eğitimi de İmam Hatipleri canlandırmak için alınmış bir karar gibi duruyor."[14-E]

"Geçiş Süreci açısından" temasıyla ilgili olarak herhangi bir olumlu görüş belirtilmemiştir. "Olumsuz Görüşler" alt temasında ise en çok "geçiş süreci hızlı oldu" ve "aksaklıklar yaşandı" görüşleri bulunmaktadır. Bu görüşlerden bazıları şunlardır:

"Geçiş süreci hızlı oldu. Kademelendirme yapılabilirdi. Örneğin, 5. sınıf öğrencilerinden itibaren başlanacağı, 2 yıl sonra başlanacağı gibi olabilirdi. Böylelikle öğretmeni ve teknolojik altyapı hazır olurdu. Zorunlu eğitimin getirmiş olduğu sorunlardan kurtulmuş olurduk." [2-E]

"Adaptasyon sürecinde sorunlar yaşandığııı düşünüyorum." [4-E]

"Çok hızl geçiş yapıldı. Fiziki ve teknik altyapı oluşturulmadan, eğitim kadrosu oluşturulmadan geçilmesinde bazı sıkıntılar oluştu." [11-E] 
"Hizmet içi eğitim açısından" temasının "Olumlu Görüşler" alt temasında en çok "hizmet içi eğitim aldım" görüşü ortaya çıkmıştır. Hizmet içi eğitim alındığına dair görüşlerden bazıları şunlardır:

"Gerekli bilgilendirmeleri aldık. Sadece yöneticiler değ il veliler ve diğer yöneticilerde katılmalı." [3-E]

"Verildi. Yapılan çalışmaların yararları, neler să̆layacă̆ı salonlarda okul müdürlerine anlatıldr." [12-E]

"Hizmet içi eğitim açısından" temasının "Olumsuz Görüşler" alt temasinda "eğitim verilmedi" görüşü ifade edilmiştir. Hizmet içi eğitim verilmediğine dair bazı görüşler şunlardır:

"Kendimiz programı inceleyerek öğrendik. Hizmet içi eğitim olursa daha faydalı olacağına inanıyorum. Hizmet içi eğitim verilmeli. Hedeflerin anlatılması ve onların görüşleri alını, tekrar gözden geçirilmeli." [7-E]

"Zorunlu eğitim ile ilgili almadım." [8-E]

Yukarıdaki ifadelerden anlaşıldığı üzere yöneticilerden planlama hakkında ortak bir görüş alınamamıştır. Planlamanın yapıldığı ve yapılmadığı şeklinde iki farklı görüş bulunmaktadır. Yöneticilerin büyük kısmının geçiş sürecinin hızlı olduğu ve bu süreçte aksaklıkların yaşandığı şeklinde görüşleri bulunmaktadır. Ayrıca yöneticilerin büyük kısmı hizmetiçi eğitim almadıklarını ifade etmişlerdir. Okul yöneticilerinin ortaöğretimin zorunlu eğitim kapsamına alınması ile birlikte liselerdeki değişiklikler hakkında görüşleri Tablo 10'da verilmiştir.

"Genel Liseler açısından" temasının "Olumlu Görüşler" alt temasında "Anadolu liseleri başarısını korudu" ve "problem yok" görüşleri ifade edilmiştir. Bu görüşlerden bazıları şunlardır:

"Şu an sınav sistemi devam ettiği için okulumuz başarısını koruyor." [15-E]

"Genel liselerde bir problem olmadığın düşünüyorum." [3-E]

"Genel Liseler açısından" temasının "Olumsuz Görüşler" alt temasında "öğrenci profili değişti" ve "öğrenci sayıları arttı" görüşleri yapılmıştır. Bu görüşlerden bazıları aşağıda belirtilmiştir:

"Böylelikle öğrenci profilinde değişimler oldu. Daha düşük seviyede öğrencilerde liseye gelmeye başladı." [1-E] 
Tablo 10. Ortaöğretimin Zorunlu Eğitim Kapsamına Alınması ile Birlikte Liselerdeki Değişiklikler ile İlgili Okul Yöneticilerinin Görüşleri

\begin{tabular}{|c|c|c|c|c|c|}
\hline Tema & f & Alt temalar & f & Yönetici Görüşleri & $\mathbf{f}$ \\
\hline \multirow{4}{*}{$\begin{array}{l}\text { Genel liseler } \\
\text { açısından }\end{array}$} & \multirow{4}{*}{8} & \multirow{2}{*}{$\begin{array}{l}\text { Olumlu görüş- } \\
\text { ler }\end{array}$} & \multirow[t]{2}{*}{2} & Anadolu liseleri başarısını korudu & 1 \\
\hline & & & & Problem yok & 1 \\
\hline & & \multirow{2}{*}{$\begin{array}{l}\text { Olumsuz gö- } \\
\text { rüşler }\end{array}$} & \multirow[t]{2}{*}{6} & Öğrenci profili değişti & 4 \\
\hline & & & & Öğrenci sayıları arttı & 2 \\
\hline \multirow{7}{*}{$\begin{array}{l}\text { Meslek liseleri } \\
\text { açısından }\end{array}$} & \multirow{7}{*}{16} & \multirow{2}{*}{$\begin{array}{l}\text { Olumlu görüş- } \\
\text { ler }\end{array}$} & \multirow[t]{2}{*}{3} & Alanlarla ilgili düzenleme yapıldı & 2 \\
\hline & & & & Meslek liseleri teknik Anadolu adını aldı & 1 \\
\hline & & \multirow{5}{*}{$\begin{array}{l}\text { Olumsuz gö- } \\
\text { rüşler }\end{array}$} & \multirow{5}{*}{13} & Hiçbir okulu kazanamayanlar geliyor & 6 \\
\hline & & & & Disiplin sorunları arttı & 2 \\
\hline & & & & Öğrenciler bilinçli olarak gelmiyor & 2 \\
\hline & & & & Anadolu Lisesi sanıp tercih yapanlar oldu & 2 \\
\hline & & & & $\begin{array}{l}\text { Gidilmek istenen bölümde yer yoksa başka bö- } \\
\text { lümlere yönlendiriliyor }\end{array}$ & 1 \\
\hline \multirow{9}{*}{$\begin{array}{l}\text { Özel liseler } \\
\text { açısından }\end{array}$} & \multirow{9}{*}{21} & \multirow{7}{*}{$\begin{array}{l}\text { Olumlu görüş- } \\
\text { ler }\end{array}$} & \multirow{7}{*}{15} & Öğrenci sayısı arttı & 4 \\
\hline & & & & Temel lise, Anadolu ve Fen liseleri adını aldı & 4 \\
\hline & & & & Okul sayısı arttı & 2 \\
\hline & & & & Devletin üzerindeki yük azalacak & 2 \\
\hline & & & & $\begin{array}{l}\text { Seviyesi düşük, maddi durumu iyi olan çocuklar } \\
\text { yönlendiriliyor }\end{array}$ & 1 \\
\hline & & & & Dershanelerin kapatılması doğru & 1 \\
\hline & & & & Özel okullar olmalı & 1 \\
\hline & & \multirow{2}{*}{$\begin{array}{l}\text { Olumsuz gö- } \\
\text { rüşler }\end{array}$} & \multirow[b]{2}{*}{6} & Haksız rekabet, devamsızlık ve not şişirme var & 5 \\
\hline & & & & $\begin{array}{l}\text { Dershane kültürü ile okul kültürü arasında boca- } \\
\text { lıyorlar }\end{array}$ & 1 \\
\hline
\end{tabular}

"Fen lisesi olarak bile 3 sinıf alırken şimdi 4 sinıf alıyoruz. 76 öğrenci alırken artık 120 öğrenci alıyoruz. Tüm Türkiye genelinde öğrenci sayısı arttı." [12-E]

"Meslek liseleri açısından" temasının "Olumlu Görüşler" alt teması incelendiğinde "alanlarla ilgili düzenleme yapıldı" ve"meslek liseleri teknik Anadolu adını aldı" şeklinde görüşler belirtilmiştir. Bu görüşleri belirten okul yöneticilerinin ifadeleri aşağıdadır:

"Meslek liselerinde alanlar ile ilgili düzenleme yapıldı. Bizim okulumuzda da yapıldı. Hemşirelik, radyoloji ve anestezi bölümlerimiz kapatıldı. Bunun yanında tüm sağlık hizmeti veren okullarda hemşire yardımcllığı, ebe yardımcılı̆̆ı ve să̆lık bakım teknisyenliği olmak üzere 3 alanda açıldı. Bu düzenleme bizi kısmen etkiledi." [5-E]

"Meslek liselerinin hepsi teknik Anadolu Lisesi oldu."[2-E]

"Meslek liseleri açısından" temasının "Olumsuz Görüşler" alt temasında ise en çok "hiçbir okulu kazanamayanlar geliyor", "disiplin sorunlar arttı" ve "öğrenciler bilinçli olarak gelmiyor" şeklinde görüşler bulunmaktadir. 
"Eskiden meslek liselerine sinavla giriliyordu. Şimdi çocuklar hiçbir yere gidemez ise meslek lisesine gidiyor." [14-E]

"Okumak istemeyen çocukları mecbur tuttuğumuz için, bunlarda zaten başarısız öğrenciler ve bizim meslek liselerini tercih ediyorlar." [13-E]

"Bizim okula gelen öğrenciler hiçbir hedefi olmadan geliyorlar. Akşama kadar bir yere zarar vermesin diye kontrol ediyoruz. Polisçilik oynuyoruz." [14-E]

".....isminde Anadolu geçtiği için düz Anadolu lisesi sanıp tercih edenler oldu okulumuzu." [2-E]

"Özel Liseler açısından" temasının "Olumlu Görüşler" alt temasında en çok "öğrenci sayısı arttı" ve "temel lise, Anadolu ve Fen liseleri" adını aldı" şeklinde görüşler belirtilmiştir. Bu görüşleri belirten okul yöneticilerinin ifadelerinden bazıları aşağıda verilmiştir:

“Özel okullar Türkiye'de şu an çok fazla talep görmeye başladı. Biraz rekabeti artiracak." [3-E]

"Dershaneler özel okullara dönüştüler. Temel lise adını aldılar. Bazı özel liseler özel Anadolu ve Fen liselerine dönüştürüldü." [2-E]

“Özel Liseler açısından” temasının "Olumsuz Görüşler" alt temasında en çok "haksız rekabet", "devamsızlık" ve "not şişirme var" görüşüne ulaşılmıştır. Bu görüşlerden bazıları aşağıda ifade edilmiştir:

“Özel liseler rekabet açısından gerekli. Fakat sistemi kontrol edemiyoruz. Bizim okulumuzda sinıfta kalan bir çocuk özel lisede takdir alabiliyor. Özel liselerin olması güzel fakat denetim mekanizmasında sıkıntılar var. Haksız rekabete yol açıyor." [10-E]

“Özel liselerdeki not sistemi çok sıkı denetlenmeli. Devamsızlı̆̆a önem vermiyorlar." [15-E]

"Program açısından devlet okullarına göre avantajlı. Bu adaletsizlik giderilmeli. Son sinıflarda bazı dersler orada zorunlu değil." [16-E]

Yukarıdaki ifadelerde görüldüğü üzere yöneticilerden bir kısmı genel liselerin ve mesleki okulların öğrenci profilinin olumsuz anlamda değiştiği şeklinde görüşler belirtmektedir. Özel liseler hakkında ise bu okullara talebin arttığ belirtilmiştir. Okul yöneticilerinin ortaöğretimin zorunlu olması ile birlikte liselerdeki öğrenme ortamları ve öğretim programları hakkında görüşleri Tablo 11'de verilmiştir. 
Tablo 11. Ortaöğretimin Zorunlu Olması ile Birlikte Liselerdeki Öğrenme Ortamları ve Öğretim Programlan ile İlgili Okul Yöneticilerinin Görüşleri

\begin{tabular}{|c|c|c|c|c|c|}
\hline Tema & $\mathrm{f}$ & Alt temalar & $\mathrm{f}$ & Yönetici Görüşleri & $\mathrm{f}$ \\
\hline \multirow{9}{*}{$\begin{array}{l}\text { Öğrenme ortam- } \\
\text { ları açısından }\end{array}$} & \multirow{9}{*}{45} & Olumlu görüş- & 23 & Teknolojik altyapı yeterli & 12 \\
\hline & & ler & & Okul binası ve derslikler yeterli & 8 \\
\hline & & & & Oyun alanları var & 3 \\
\hline & & & & Sosyal alanları kapattık & 6 \\
\hline & & & & Okul kapasitesi yetmedi & 5 \\
\hline & & Olumsuz gö- & 22 & Spor salonu yok & 4 \\
\hline & & rüşler & & Öğrenci sayıları arttı & 4 \\
\hline & & & & Eğitim-öğretime uygun değil & 2 \\
\hline & & & & Bir gecede meslek lisesi oldu & 1 \\
\hline \multirow{9}{*}{$\begin{array}{l}\text { Öğretim prog- } \\
\text { ramları açısın- } \\
\text { dan }\end{array}$} & \multirow{9}{*}{18} & Olumlu görüş- & 11 & Değişiklikler yapılıyor & 8 \\
\hline & & ler & & Köklü değişim planlanıyor & 1 \\
\hline & & & & Yeni taslakta hafifleyecek & 1 \\
\hline & & & & Modüler eğitim sistemine geçildi & 1 \\
\hline & & & & Değişiklik var ama yeterli değil & 2 \\
\hline & & & & Bütün liselerde aynı müfredat olması yanlış & 2 \\
\hline & & Olumsuz gö- & 7 & Öğretmenler adapte olamadı & 1 \\
\hline & & rüşler & & Öğretmenler yetersiz & 1 \\
\hline & & & & Değişikliler ihtiyaca yönelik değil & 1 \\
\hline
\end{tabular}

“Öğrenme Ortamları açısından" temasının "Olumlu Görüşler" alt temasında en çok "teknolojik altyapr yeterli" ve "okul binası ve derslikler yeterli" şeklinde görüşler belirtilmiştir. Bu görüşlerden bazıları aşağıda verilmiştir:

"Okullar donanım olarak gayet iyi. 15 yıl öncesine göre iyi. Teknolojik olarak, derslik, donanm olarak gayet iyi."[12-E]

"Okul binamiz ve dersliklerimiz yeterli." [13-E]

"Öğrenme Ortamları açısından" temasının "Olumsuz Görüşler" alt temasında en çok "sosyal alanları kapattık" ve "okul kapasitesi yetmedi" şeklinde görüşler belirtilmiştir. Bu görüşlerden bazıları aşağıda verilmiştir:

"Ĕğitim alanları oluşturmak için sosyal alanlardan feragat ettik." [2-E]

"Bizim okul 500 kişilik bir okul. Zorunlu eğitim olduktan sonra 1000 civarna çıktı. Temel liseler açıldıktan sonra tekrar 800 civarına düştü. Okulun kapasitesi yetmiyordu." [2-E]

"Öğretim Programları açısından" temasının "Olumlu Görüşler" alt temasında en çok "değişiklikler yapılıyor" görüşü ifade edilmiştir. Bu görüşlerden bazıları aşağıda belirtilmiştir:

"Müfredatta sürekli değgişiklikler yapılıyor. Eğitim sürekli değişken."[1-E] 
“Dönemsel olarak değişiklik yapılıyor. Müfredat sadeleştirmeye gidiliyor. Öğretmenlerimizin yeni müfredat için görüşleri alınıyor bu aralar. "[12-E]

"Son zamanlarda bir müfredat çalışması yapıldı. Tüm öğretmenlerden görüş alındı. Tabanın görüşleri dikkate alınarak yapıldı. Iyi bir müfredatın önümüze geleceğini umuyoruz." [5-E]

"Öğretim Programları açısından" temasının "Olumsuz Görüşler" alt temasında en çok "değişiklik var ama yeterli değil" ve "bütün liselerde aynı müfredat olması yanlış" görüşleri ifade edilmiştir. Bu görüşleri belirten okul yöneticilerinin ifadeleri aşağıda verilmiştir:

"Müfredatta ufak çaplı değ işiklikler oluyor. Fakat öğrencilerin ihtiyaçlarına yönelik değil." [13-E]

"Müfredat ile öğrenci hayatını yakınlaştırmaya çalışıyoruz. Aşırı bilgi yüklemesinden kaçınıyoruz. Değişiklikler var fakat yeterli değil." [7-E]

"Fakat şu an liselerde 9. ve 10. sinıflarda aynı müfredat işleniyor. Aynı dersler var. Fen lisesi için kolay gelirken meslek liselerindeki çocuklar zorlanıyor. Ortak deneme sinavları yapilyor." [12-E]

Yukarıdaki yönetici ifadelerinden anlaşıldığı üzere okullar teknolojik açıdan yeterli bulunmaktadır. Yöneticilerin büyük kısmı derslikleri de yeterli bulmaktadır. Fakat bazı eski okullarda dersliklerin yetersiz olduğu düşünülmektedir. Yöneticilerin bir kısmı spor alanlarının ve sosyal alanların kısıtlı olduğunu da belirtmektedir. Öğretim programları ise yöneticilerin büyük kısmı tarafından güncel bulunmaktadır. Okul yöneticilerinin ortaöğretimin zorunlu olması ile birlikte ortaöğretime geçiş sistemi ve mesleki rehberlik hakkında görüşleri Tablo 12' de verilmiştir.

"Ortaöğretime Geçiş Sistemi Açısından" temasında herhangi bir olumlu ve olumsuz görüş bulunmamakla birlikte bazı öneriler yapılmıştır. "Öneriler" alt temasında en çok "sınav olması gerekir" ve "yönlendirme yapılmalı" şeklinde görüşlere ulaşılmıştır. Bu görüşlerden bazıları aşağıda verilmiştir:

“Veli çocuğunun iyi bir okulda eğitim görmesini istiyor. Belli okullara yüklemeler oluyor. Veli okula bă̆ış yapıyor. İkametgâh ile alınınca değişiklik yapılıyor. Sınav sisteminin daha adil olduğunu düşünüyorum."[1-E]

"Sınav olmalı. Belli bir puanın altındaki öğrenci açık liseye direk kayıt yapılmal. Çocukları hiç istemedikleri liselere yerleştirmede yapilabiliyor." [13-E]

"Rehber öğretmen görüşü de olmalı. Yetenek anketleri ile olmall. Yönlendirme ilk 4'te olmalı. Akademik başarı da dikkate alınmalı." [2-E] 
Tablo 12. Ortaöğretime Geçiş Sistemi ve Mesleki Rehberlik ile İlgili Okul Yöneticilerinin Görüşleri

\begin{tabular}{|c|c|c|c|c|c|}
\hline Tema & $\mathbf{f}$ & Alt temalar & $\mathbf{f}$ & Yönetici Görüşleri & $\mathbf{f}$ \\
\hline \multirow{9}{*}{$\begin{array}{l}\text { Ortaöğretime } \\
\text { geçiş sistemi } \\
\text { açısından }\end{array}$} & \multirow{9}{*}{21} & \multirow{9}{*}{ Öneriler } & \multirow{9}{*}{21} & Sinav olması gerekir & 9 \\
\hline & & & & Yönlendirme yapılmalı & 5 \\
\hline & & & & Başarısız öğrenci meslek lisesine gitmeli & 1 \\
\hline & & & & Mevcut notları ile olmalı & 1 \\
\hline & & & & Öğrenci istemediği liseye yerleştirilmemeli & 1 \\
\hline & & & & Düşük puanlı açık liseye yönlendirilmeli & 1 \\
\hline & & & & Meslek lisesi için beceri testi olmalı & 1 \\
\hline & & & & Daha çok sınav olmalı & 1 \\
\hline & & & & Sinav olmazsa bir kriter olmalı & 1 \\
\hline \multirow{6}{*}{$\begin{array}{l}\text { Mesleki reh- } \\
\text { berlik açısın- } \\
\text { dan }\end{array}$} & \multirow{6}{*}{17} & \multirow{6}{*}{$\begin{array}{l}\text { Olumlu gö- } \\
\text { rüşler }\end{array}$} & \multirow{6}{*}{17} & Bilgilendirme yapılıyor & 12 \\
\hline & & & & Görsel ve sosyal medya ile bilgi alıyorlar & 1 \\
\hline & & & & Veli iletişimleri önemli & 1 \\
\hline & & & & Yeteneklere göre çalışmalar var & 1 \\
\hline & & & & Kariyer günleri var & 1 \\
\hline & & & & Geziler var & 1 \\
\hline
\end{tabular}

“Öğretmenler bir rapor hazırlayıp, bu raporlar doğrultusunda karar verilmeli. Veli itiraz edebilir. Tekrar bir sinav yapılıp geçerse, akademik eğitime yönlendirilebilir." [3-E]

“Öğrenci ne olmak istediğine karar verecek. Öğrenci ortaokulda yönlendirilecek. Sağlam ve bağlayıcı bir karar veren yönlendirici öğrenci formu olacak. Ortaokulda meslek lisesine gitmesi gerekiyor deniyorsa oraya gidecek, diğer okullara deniyorsa oraya gidecek." [14-E]

"Mesleki Rehberlik açısından" temasının "Olumlu Görüşler" alt temasinda en çok "bilgilendirme yapılıyor" görüşü bulunmaktadır. Olumlu görüşlerden bazıları aşağıda verilmiştir. Bu tema altında herhangi bir olumsuz görüş bulunmamaktadır. Olumlu görüşlerden bazıları aşağıda belirtilmiştir:

"Yal içerisinde bilgilendirmeler yapılıyor. Toplantılar yapılıyor. Tercih dönemlerinde öğretmenlerden oluşan komisyonlar kuruyoruz." [1-E]

"Bilgilendirme oluyor. Mesleki rehberlik ve eğitsel rehberlik alanında gerekli çalışmaları yapıyoruz." [8-E]

"Meslek bilgilerine 11. sinffta başlyyoruz. GOP üniversitesinden yardım alıyoruz. Tıp, Diş hekimliği fakültelerinden hocalar gelip, bilgi aktarıyorlar. Ankara ve İstanbul'da üniversiteler gezdiriliyor." [12-E]

Yukarıdaki ifadelerde görüldüğü gibi yöneticilerin büyük kısmı ortaöğretime geçişte bir sınavın olması gerektiğini ve liselerde mesleki rehberlik konusunda bilgilendirmenin yapıldığını belirtmektedir. Ortaöğretimin 
zorunlu eğitim kapsamına alınması sonucunda eğitimin niteliğine ilişkin yönetici görüşleri Tablo 13'de verilmiştir.

Tablo 13. Ortä̈̆retimin Zorunlu Eğitim Kapsamına Alınması Sonucunda Eğitimin Niteliği ile İlgili Okul Yöneticilerinin Görüşleri

\begin{tabular}{|c|c|c|c|c|c|}
\hline Tema & $\mathrm{f}$ & Alt temalar & f & Yönetici Görüşleri & $\mathrm{f}$ \\
\hline \multirow[b]{2}{*}{$\begin{array}{l}\text { Eğitimin ni- } \\
\text { teliği açısın- } \\
\text { dan }\end{array}$} & \multirow[b]{2}{*}{19} & $\begin{array}{l}\text { Olumlu görüş- } \\
\text { ler }\end{array}$ & 3 & Eğitimin kalitesi etkilenmedi & 3 \\
\hline & & $\begin{array}{l}\text { Olumsuz gö- } \\
\text { rüşler }\end{array}$ & 16 & $\begin{array}{l}\text { Eğitimin kalitesi olumsuz etkilendi } \\
\text { Lisede okuma bilmeyen öğrenciler var } \\
\text { Sınıf geçme sistemi olumsuz etkilendi } \\
\text { İlgisiz ögrenci arttı } \\
\text { Kaynaştırma eğitimi ile ilgili altyapı yok } \\
\text { Öğrenci istemediği bölümlere yerleştiriliyor } \\
\text { Belli seviyenin altındaki okullar olumsuz etki- } \\
\text { lendi }\end{array}$ & $\begin{array}{l}8 \\
3 \\
1 \\
1 \\
1 \\
1 \\
1\end{array}$ \\
\hline $\begin{array}{l}\text { Ortaokuldaki } \\
\text { akademik } \\
\text { başarının li- } \\
\text { seye yansı- } \\
\text { ması açısın- } \\
\text { dan }\end{array}$ & 26 & $\begin{array}{l}\text { Olumsuz gö- } \\
\text { rüşler }\end{array}$ & 26 & $\begin{array}{l}\text { Notlar şişirme } \\
\text { Veliler düşük nota itiraz ediyor } \\
\text { Özel okullarda daha fazla şişirme not var } \\
\text { Okul idaresi şişirme notu destekliyor }\end{array}$ & $\begin{array}{l}17 \\
4 \\
4 \\
1\end{array}$ \\
\hline \multirow[b]{2}{*}{$\begin{array}{l}\text { Öğrencilerin } \\
\text { lisedeki te- } \\
\text { mel dersler- } \\
\text { deki durumu } \\
\text { açısından }\end{array}$} & \multirow[b]{2}{*}{18} & $\begin{array}{l}\text { Olumlu görüş- } \\
\text { ler }\end{array}$ & 1 & Öğrenciler lise 1'de yeterli & 1 \\
\hline & & $\begin{array}{l}\text { Olumsuz gö- } \\
\text { rüşler }\end{array}$ & 17 & $\begin{array}{l}\text { Öğrenciler lise 1'de yetersiz } \\
\text { Meslek liseleri öğrencisi daha fazla yetersiz } \\
\text { Devamsızlık ve sınıf tekrarı sorunu var } \\
\text { İşleme dayalı eğitimden dolayı sıkıntı oluyor }\end{array}$ & $\begin{array}{l}11 \\
3 \\
2 \\
1\end{array}$ \\
\hline
\end{tabular}

"Eğitimin niteliği açısından" teması "Olumlu görüşler" alt temasında "eğitimin kalitesi etkilenmedi" görüşü ifade edilmiştir. Liselerde eğitimin kalitesinin etkilenmediğine dair ifadeler aşağıdadır:

"Eğitimin kalitesi zorunlu eğitimden etkilenmedi." [8-E]

"Kalite olumsuz yönde etkilenmedi. Çocuklar bizim okulumuzu seçerek geldikleri için bir problem olmadı. Sinıf mevcutlarımız 30'dan 34'e çıktı. Fakat eğgitim ortamımı etkilenmedi." [16-E]

"Eğitimin niteliği açısından" teması "Olumsuz görüşler" alt temasında ise en çok "eğitimin kalitesi olumsuz etkilendi" ve "lisede okuma bilmeyen öğrenciler var" görüşleri ifade edilmiştir: Okul yöneticilerinin ifadelerinden bazıları şunlardır:

"Önceleri veli, çocuğu çok düşük seviyede ise sanayiye meslek sahibi olması için veriyordu. Birden zorunlu eğitim gelince bütün öğrenciler liselere akın etti. Kalite açısından düşme oldu." [5-E] 
"Okumak isteyen ve okumak istemeyenler bir arada olunca eğitim ortamı çok olumsuz etkilendi." [13-E]

"Meslek liselerinde temel eğitimden okuma yazma bilmeden gelen çocuklar var." [8-E]

"Ortaokuldaki akademik başarının liseye yansıması açısından" teması incelendiğinde herhangi bir olumlu görüş bulunmamaktadır. "Olumsuz görüşler" alt temasında ise "notlar şişirme" ve "veliler düşük nota itiraz ediyor" şeklinde belirtenler bulunmaktadır.

"Notlar şişirme oluyor. Özel okullarda daha fazla oluyor. Hatta bazı öğrenci ve veliler sirf bu yüzden bu okullarn tercih ediyorlar." [1-E]

"Çocuklara şişirilmiş notlar veriliyor." [16-E]

"Özel okullar, öğrenciler not kaygısı yaşatmıyor. Şişirme notlar veriliyor. Haksız rekabet oluşuyor. Liselerde de aynı şekilde durumlar var. Veliler öğrencilerin notlarım 100 olmasın istiyor." [12-E]

"Veliler çocuklarının ortaokulda çok yüksek not alırken lise 1'de düşük not almasina itiraz ediyorlar." [1-E]

"Öğrencilerin lisedeki temel derslerdeki durumu açısından" temasinda "Olumlu görüşler" alt temasında sadece bir yönetici "öğrenciler lise 1'de yeterli" görüşünü belirtmiştir. Bu görüş aşağıda ifade edilmiştir:

"Bizim okulumuza gelen çocuklar, temel dersler açısından yeterli." [8-E]

"Öğrencilerin lisedeki temel derslerdeki durumu açısından" temasinda "Olumsuz görüşler" alt temasında en çok "öğrenciler lise 1'de yetersiz" görüşü ifade edilmiştir: Bu görüşlerden bazıları şunlardır:

"Yeterli olmadığını düşünüyorum. Diğer meslek lisesi türlerinde özellikle akademik düşüklük gözleniyor." [5-E]

"Illköğretimde kalite çok düşük. Yetersiz geliyorlar." [14-E]

"Temel derslerde yetersizlikler görüyoruz. 9. sinıfta çocuklarda biraz rehavet oluşuyor. Genelde ilk sinavlarda çok düşük notlar alınıor." [16-E]

Yukarıdaki ifadelerden anlaşıldığı üzere yöneticilerin büyük kısmı zorunlu ortaöğretim ile birlikte eğitimin kalitesinin olumsuz etkilendiğini, okullarda notların abartılı olduğunu ve öğrencilerin liseye başladıklarında temel derslerde yetersiz olduğunu ifade etmişlerdir. Fakat eğitimin kalitesinin etkilenmediğine dair görüşlerde bulunmaktadır. Ortaöğretimin zorunlu eğitim kapsamına alınması ile beraber Türk eğitim sistemindeki değişikliklere ilişkin yönetici görüşleri Tablo 14'de verilmiştir. 
Tablo 14. Ortaöğretimin Zorunlu Ĕ̆itim Kapsamına Alınması ile Beraber Türk Ĕ̆itim Sistemindeki Değişiklikler ile İlgili Okul Yöneticilerinin Görüşleri

\begin{tabular}{|c|c|c|c|c|c|}
\hline Tema & f & Alt temalar & f & Yönetici Görüşleri & $\mathbf{f}$ \\
\hline \multirow{4}{*}{$\begin{array}{l}\text { Eğitim sistemi } \\
\text { açısından }\end{array}$} & \multirow{4}{*}{11} & Olumlu görüş- & 8 & Bütün liseler Anadolu adını aldı & 6 \\
\hline & & ler & & Okulların kapasitesi artırıldı & 1 \\
\hline & & & & Kız öğrenci sayısı arttı & 1 \\
\hline & & $\begin{array}{l}\text { Olumsuz gö- } \\
\text { rüşler }\end{array}$ & 3 & $\begin{array}{l}\text { Eğitim sisteminde herhangi bir değişik- } \\
\text { lik olmadı }\end{array}$ & 3 \\
\hline
\end{tabular}

"Eğitim sistemi açısından" teması "Olumlu görüşler" alt teması incelendiğinde "bütün liseler Anadolu adın aldı", "okulların kapasitesi artırıldı" ve "kız öğrenci sayısı arttı" görüşleri belirtilmiştir. Bu görüşleri belirten okul yöneticilerinin ifadeleri aşağıdadır:

"Meslek liseleri Teknik Anadolu ve genel liseler Anadolu Lisesi oldu." [5-E]

"Tüm okulların kapasitesi artırıldı." [2-E]

"Kız öğrenci sayısında artış görüyoruz. Hiçbir öğrenci göndermeyen bölgelerden öğrenci gelmeye başladı." [3-E]

"Eğitim sistemi açısından" teması "Olumsuz görüşler" alt temasında ise eğitim sisteminde "herhangi bir değişiklik yok" görüşüne ulaşılmıştır. Bu görüşlerden bazıları aşağıda verilmiştir:

"Ben bir değişiklik görmedim. Sadece akıllı tahtalar ve Fatih projesi. Buda zorunlu eğitim ile alakalı değildi zaten." [4-E]

"Değişim olmadı. Herkesi zorla okutmaya başladık. Müfredatın içini boşalttık. Çünkü herkesin liseyi bitirmesi gerekiyor." [6-E]

Yukarıdaki ifadelerde görüldüğü gibi bazı yöneticiler, genel liselerin Anadolu liselerine dönüştürülmesini olumlu bir gelişme olarak belirtmektedir. Fakat eğitim sisteminde herhangi bir değişikliğin olmadığına dair görüşlerde bulunmaktadır. Ortaöğretimin zorunlu eğitim kapsamına alınmasının sağladığı gelişmeler ile ilgili yönetici görüşleri Tablo $15^{\prime}$ de verilmiştir.

“Ortaöğretimin zorunlu eğitim kapsamına alınmasının sağladığı gelişmeler" teması "Olumlu görüşler" alt temasında en çok "üniversiteye giden öğrenci sayısı ve mezunu arttı" ve "kırsaldaki çocuklar okula kazandırıldı" görüşleri belirtilmiştir.

"Üniversiteye giden öğrenci sayısı arttı. Öğrencilerin ufku arttı. En vasat öğrenciler bile üniversite eğitiminden olumlu etkileniyor." [2-E] 
"Kız öğrencileri açısından Anadolu'da erken evlilik var. Kızların eğitimi artacak. Yatılı pansiyonumuzda 100 tane öğrenci kalıyor. Bunların hepsi köyden geliyor. Zorunlu eğitim olmasaydı belki yarısı devam etmezdi." [16-E]

Tablo 15. Ortaöğretimin Zorunlu Eğitim Kapsamına Alınmasının Sağladığı Gelişmeler ile İlgili Okul Yöneticilerinin Görüşleri

\begin{tabular}{|c|c|c|c|c|c|}
\hline Tema & $\mathbf{f}$ & Alt temalar & $\mathbf{f}$ & Yönetici Görüşleri & $\mathbf{f}$ \\
\hline \multirow{26}{*}{$\begin{array}{l}\text { Ortaöğretimin } \\
\text { zorunlu eğitim } \\
\text { kapsamına alın- } \\
\text { masının sağla- } \\
\text { dığı gelişmeler }\end{array}$} & \multirow{26}{*}{48} & \multirow{10}{*}{$\begin{array}{l}\text { Olumlu görüş- } \\
\text { ler }\end{array}$} & \multirow{10}{*}{20} & Üniversite öğrencisi ve mezunu sayısı arttı & 5 \\
\hline & & & & Kırsalda ki çocuklar okula kazandırıldı. & 4 \\
\hline & & & & Olumsuz bir özelliği yok & 3 \\
\hline & & & & Mesleki eğitim örgün eğitime dâhil oldu & 2 \\
\hline & & & & Düşük seviyede öğrenciler liseye geldi & 1 \\
\hline & & & & Öğrencilerin ufkunu açtı & 1 \\
\hline & & & & Okul türlerine göre olumlu ya da olumsuz & 1 \\
\hline & & & & AB ile aynı şartlarda mücadele edeceğiz & 1 \\
\hline & & & & Yetişmiş insan gücü artacaktır & 1 \\
\hline & & & & Ekonomiyi canlandırır. & 1 \\
\hline & & \multirow{16}{*}{$\begin{array}{l}\text { Olumsuz gö- } \\
\text { rüşler }\end{array}$} & \multirow{16}{*}{28} & Ara eleman sıkıntısı oluştu & 4 \\
\hline & & & & Fiziksel ortamı olumsuz etkiledi & 3 \\
\hline & & & & Eğitimin kalitesi olumsuz etkilendi & 3 \\
\hline & & & & Düşük seviyede öğrenciler gelmeye başladı & 2 \\
\hline & & & & Kırsaldan şehre insanlar göç etti & 2 \\
\hline & & & & Liseden sonra meslek öğretilemiyor & 2 \\
\hline & & & & Çocukları zorla okula getirmek & 2 \\
\hline & & & & Devamsızlık sorunu oluştu & 2 \\
\hline & & & & Sadece akademik başarıya göre liseye yerleşti & 1 \\
\hline & & & & Herkesin lise diploması alması & 1 \\
\hline & & & & Okullara fazladan yük getirdi & 1 \\
\hline & & & & Üst kuruma hazırlamada liseler yetersiz kaldı & 1 \\
\hline & & & & Meslek liselerinin başarısı düştü & 1 \\
\hline & & & & Öğrenciler istemedikleri liselere yerleştiriliyor & 1 \\
\hline & & & & Herkesin lise eğitiminin içinde olması & 1 \\
\hline & & & & Disiplin sorunları arttı & 1 \\
\hline
\end{tabular}

"Kız çocukları eğitimin içine girdi. Okumak istiyor çocuk ama veli istemiyor. Çocuk çalıştırllıyor. Bu çocuklarda eğitimin içine giriyor." [7-E]

“Ortaöğretimin zorunlu eğitim kapsamına alınmasının sağladığı gelişmeler" teması "Olumsuz görüşler" alt temasında "ara eleman sıkıntısı oluştu", "fiziksel ortamı olumsuz etkiledi" ve "eğitimin kalitesi olumsuz etkilendi" görüşleri ortaya çıkmıştır. Bu görüşlerden bazıları aşağıda verilmiştir:

"Herkesi okutmak zorunda değiliz. Ara eleman sıkıntısı oluştu." [1-E]

"Kademeli olarak geçmememiz fiziksel ortamımızı olumsuz etkiledi. Bu da kalitemizi etkiledi. Kalitenin eski haline gelmesi zaman alacaktı." [2-E]

"Ĕ̈itimin kalitesi düşüyor." [13-E] 
"En tehlikeli insan amacı olmayan insandır. Lisede amaçsız, hedefsiz çok fazla öğrenci oluştu." [14-E]

Yukarıdaki ifadelerde görüldüğ̈ü gibi yöneticilerin bir kısmı zorunlu ortaöğretim ile birlikte üniversite öğrenci sayısının artacak olmasını ve kırsaldaki çocukların okula kazandırılacak olmasını olumlu bir gelişme olarak belirtmişlerdir. Bir kısım yönetici ise zorunlu ortaöğretim ile birlikte ara elaman eksikliği oluşacak olmasını olumsuz bir gelişme olarak ifade etmişlerdir.

Ortaöğretimin zorunlu eğitim kapsamına alınmasının okul idaresine getirmiş olduğu ek iş yükü açısından yönetici görüşleri Tablo 16' da verilmiştir.

Tablo 16. Ortaöğretimin Zorunlu Eğitim Kapsamına Alınmasının Okul İdaresine Getirmiş Olduğu İş Yükü ile İlgili Okul Yöneticilerinin Görüşleri

\begin{tabular}{llllll}
\hline Tema & $\mathbf{f}$ & Alt temalar & $\mathbf{f}$ & Yönetici Görüşleri & $\mathbf{f}$ \\
\hline & & Olumlu görüşler & 12 & Ek iş yükü getirmedi & 12 \\
\cline { 3 - 5 } & & & Öğrenci sayısı arttı & 4 \\
Ek iş yükü açı- & 21 & & & Ek iş yükü oldu & 2 \\
sindan & & & Velileri ikna çabası oldu & 1 \\
& & & & İkili eğitimde ek iş yükü & 1 \\
& & & oldu & \\
& & & Disiplin sorunları oluştu & 1 \\
\hline
\end{tabular}

“Ek iş yükü açısından" teması "Olumlu görüşler" alt temasında " $e k$ iş yükü getirmedi" görüşüne ulaşılmıştır. Ortaöğretim zorunlu olduktan sonra okul yöneticilerine ek iş yükü oluşmadığına dair ifadelerden bazıları aşağıda verilmiştir:

"Ek iş yükü yok." [4-E]

"Evrak yükü olarak fazla yok. Öğrenci sayısı arttı." [14-E]

"Ek iş yükü açısından" teması "Olumsuz görüşler" alt temasında "öğrenci sayısı arttı"," ek iş yükü oldu", "ikili eğitimde ek iş yükü oldu" ve "velileri ikna çabası oldu" görüşleri bulunmaktadır. Bu görüşleri belirten okul yöneticilerinin ifadelerinden bazıları aşağıda verilmiştir:

“Öğrenci sayısı arttı." [2-E]

"Bazı okullar ikili eğitime geçtiler. Onlara fazla yük getirdi." [5-E]

"Veliler ile ilgili konuşmalar, ikna çabalarımız oldu." [4-E] 
Yöneticilerin büyük kısmı zorunlu ortaöğretim ile birlikte kendisine ek iş yükü oluşmadığını ifade etmişlerdir. Bir kısım yönetici ise öğrenci sayısının arttığını belirtmiştir. Açık lise eğitimi hakkında yönetici görüşleri Tablo 17'de verilmiştir.

Tablo 17. Açık Lise Eğitimi ile İlgili Okul Yöneticilerinin Görüşleri

\begin{tabular}{|c|c|c|c|c|c|}
\hline Tema & $\mathrm{f}$ & Alt temalar & $\mathrm{f}$ & Yönetici Görüşleri & $\mathbf{f}$ \\
\hline \multirow{16}{*}{$\begin{array}{l}\text { Açık lise } \\
\text { eğitimi hak- } \\
\text { kında gö- } \\
\text { rüşler }\end{array}$} & \multirow{16}{*}{50} & \multirow{7}{*}{$\begin{array}{l}\text { Olumlu gö- } \\
\text { rüşler }\end{array}$} & \multirow{7}{*}{21} & Açık lise gerekli & 5 \\
\hline & & & & Zamanında okumayanlar için fırsat & 5 \\
\hline & & & & Açık lise olumlu & 3 \\
\hline & & & & Mesleki dersler yüz yüze veriliyor & 3 \\
\hline & & & & Örgün eğitime devamı engellemez & 3 \\
\hline & & & & Örgün eğitime devamı engellemez & 1 \\
\hline & & & & Hem çalışıp hem okuyanlar var & 1 \\
\hline & & \multirow{9}{*}{$\begin{array}{l}\text { Olumsuz gö- } \\
\text { rüşler }\end{array}$} & \multirow{9}{*}{29} & Örgün eğitimin yerini tutmaz & 13 \\
\hline & & & & Örgün eğitimden kaçış yolu olabilir & 5 \\
\hline & & & & Problem yaşanılan öğrenciler yönlendirilebilir & 3 \\
\hline & & & & Örgün eğitime devamı engeller & 2 \\
\hline & & & & Açlk lise sistemini olumsuz buluyorum & 2 \\
\hline & & & & İnsanlar sadece diploma sahibi oluyor & 1 \\
\hline & & & & İşsiz insan sayısı az gözüküyor & 1 \\
\hline & & & & Örgün eğitime devamı engeller & 1 \\
\hline & & & & İsteksiz gelenler disiplin sorunları oluşturdu & 1 \\
\hline
\end{tabular}

"Açık lise eğitimi hakkında görüşler" temasında "Olumlu görüşler" alt temasında en çok "açık lise gerekli" ve "zamanında okumayanlar için firsat" şeklinde görüşler belirtilmiştir. Bu görüşlerden bazıları aşağıda verilmiştir:

“Gerekli. Çeşitli sebeplerle eğitime ulaşamayan insanlara bir çare olarak görüyorum." [5-E]

"Örgün eğitime devam edemeyen ve pişman olan kişilerin, kendisini yetiştirmek isteyen kişiler için faydah olacağını düşünüyorum." [13-E]

"Açık lise eğitimi hakkında görüşler" temasında "Olumsuz görüşler" alt temasi incelendiğinde "örgün eğitimin yerini tutmaz" ve "örgün eğitimden kaçıs yolu olabilir" şeklinde görüşler belirtilmiştir:

"Tutmaz. Çocuk dersi dinleyerek yapamamışken, açık liseye gidip ders dinleyeceğini düşünmüyorum." [4-E]

"Tutmaz. Açık lisedeki çocuklar çok fazla ders çalışmaz. Çok istekli götürmeyecektir." [10-E]

"Göndermek istemeyenler, açık liseyi sadece kayıt yaptırarak bu sistemi kullanıyor." [2-E] 
“Olumsuz olarak, bir kaçış olarak görülebilir. Öğrenci ya da veli açık liseden bitirmek kolaycılı̆̆ı yapabilir." [1-E]

Yukarıdaki ifadelerden anlaşıldığı üzere yöneticilerin tamamına yakını açık lisenin örgün eğitimin yerini tutmayacağını belirtmektedir. Bazı yöneticiler açı lise sisteminin gerekli olduğunu, bazı yöneticiler geçmişte okuyamayanlar için bir fırsat olduğunu ve bazı yöneticiler ise özellikle kırsal kesimde örgün eğitimden kaçış yolu olabileceğini ifade etmişlerdir.

Okul yöneticilerine ortaöğretim sisteminde değişiklik önerileri sorulmuştur. Yöneticilerin önerileri şunlardır:

"Mesleki eğitime önem verilmeli."

"Öğrenciler ortaokulda yönlendirilmeli."

"Çıraklık ve halk eğitim merkezleri yaygınlaştırılmalı."

"Başarısı düşük olan çocuklar mesleki okullara yönlendirilmeli."

"Ders saatleri azaltılmalı."

"Sosyal etkinlikler artırılmalı."

"Akademik eğitim ile Mesleki eğitim farklı olmalı."

"İki tür lise olmalı."

"Öğrenciler okulunu seçmeli."

"Mesleklerde alanında ĕğitim alma şartı olmalı."

"Öğrenciler istedikleri bölüme gitmeli."

"Meslek liselerin orta kısmı olmalı."

"Açık lise teşvik edilmeli."

"Kaynaştırma ĕgitimi ile ilgili tedbirler alınmalı."

"Meslek liselerinde daha farkl bölüm olmalı."

\section{Tartışma, Sonuç ve Öneriler}

Ortaöğretimin zorunlu öğretim kapsamına alınmasına ilişkin öğretmen görüşleri incelendiğinde öğretmenlerin bir kısmının liselerin zorunlu olmasının doğru olduğunu ifade eden görüşleri olduğu görülmüştür. Başkaya (2016) 4+4+4 kesintili zorunlu eğitim sistemi ile ilgili öğretmen görüşlerine baktığı çalışmasında zorunlu eğitimin 12 yıl ve kesintili olmasının olumlu karşılandığını belirtmiştir. Çapar (2015)'ın çalışmasında da öğretmenler zorunlu eğitimin 12 yıla çıkmasını olumlu bulmuştur. Fakat öğretmenlerin büyük kısmının zorunlu ortaöğretimin yanlış olduğu ve öğ- 
renci seviyesinde ciddi bir düşme gözlemlediklerini ifade ettikleri görülmüştür. Başaran (2016)'ın araştırmasında öğretmenler yeni sistemin öğrenciler için atılmış olumlu bir adım olmadığını düşünmektedir. Kılınç (2014)'ın araştırmasında da katılımcılar yeni eğitim sistemi ile ilgili olarak genellikle olumsuz görüş belirtmişlerdir. Tok (2013)'un çalışmasında branş öğretmenlerinin çoğunluğu ortaöğretimin zorunlu olmasını olumsuz bulduklarını ifade etmiştir.

Öğretmenlerden ortaöğretim zorunlu yapılırken planlama yapıldığını belirten sadece bir görüş vardır. Fakat öğretmenlerin büyük bir kısmının planlamanın yapılmadığını ve alınan kararların siyasi olduğunu ifade ettikleri görülmektedir. Kılınç (2014)'ın araştırmasında da yeni eğitim sistemi oluşturulurken eğitsel ihtiyaçların yeterince ön planda olmadığı görüşü ortaya çıkmıştır.

Bu çalışmada ortaöğretimin zorunlu olması sürecinin çok hızlı olduğunu ifade eden öğretmen görüşleri bulunmaktadır. Akkan (2013)'ın araştırmasında öğretmenler $4+4+4$ eğitim sistemine geçiş aşamasında planlama ve hazırlık evrelerine yeterince önem verilmediğini ve böylelikle öğretmenlerin yeni sistemi zor kabulleneceklerini ve $4+4+4$ eğitim sisteminde hedeflerin gerçekleşmesinin zorlaşacağ1 görüşünü belirtmişlerdir. Çamlıbel (2015)'in çalışmasında öğretmenler ve yöneticiler, zorunlu eğitimin 12 yıla çıkarılmasını desteklerken, sistemde yapılan değişiklikler sırasında izlenen yöntemden rahatsız olduklarını ifade etmiştir.

Genel olarak öğretmenler liselerin zorunlu olması ile ilgili hizmet içi eğitim almadıklarını ifade etmişlerdir. Öğretmenlerin yeni uygulanacak eğitim sistemi hakkında hizmetiçi eğitim almalarının o sistemin içindeki uygulayıcılardan biri olmaları nedeniyle önemli olduğu düşünülmektedir. Çünkü önce kendilerinin yeni uygulanacak sistemin amaçlarını kavramalarının önemli olduğu düşünülmektedir. Akkan (2013) araştırmasına katılan öğretmenlerin, yeni sistemin kazanımlarının önemini yeterince kavrayamadıklarını bu da öğretmenlerin kafalarında soru işareti olarak kaldığını belirtmiştir. Öğretmenlerin bir kısmı genel liselerin ve imam hatip liselerinin adlarının başına sadece "Anadolu" kelimesinin getirildiğini, başka hiçbir değişiklik olmadığını ifade etmiştir. Ayrıca ortaöğretimin zorunlu olması sonucunda genel liselerin olumsuz etkilendiği, davranış problemlerinin arttığı ve bu okullarda başarının ve öğrenci profilinin düştüğü de ifade edilmiştir. Öğretmenlerin, meslek liselerinin ortaöğretimin 
zorunlu olmasından olumsuz etkilendiğini ifade ettikleri görülmüştür. Ayrıca bu okullarda öğrenci profilinin düştüğü hatta okuma yazma bilmeyen öğrencilerin olduğu ve bu okullarda eğitim kalitesinin düştüğü ifade edilmektedir. Çamlıbel (2015) araştırmasında mesleki yönlendirmenin çok erken yaşlarda yapılmasının sakıncalı olduğunu belirtmiştir. Ercan (2016)'ın çalışmasında katılımcıların verdikleri cevapların ortalamasına bakıldığında katılımcılar, İmam-Hatip okulları dışındaki meslek okullarının da orta kısımlarının açılması gerektiğini belirtmişlerdir. Tok (2013)'un araştırmasında öğretmenler sadece İmam-Hatip Liselerinin ortaokullarının değil bütün meslek liselerinin orta kısmının açılması gerektiğini belirtmişlerdir. Ayrıca öğretmenler, meslek liselerinde öğrenci sayısının artmasını da olumlu bulmaktadır. Güven (2012, s.20) ise diğer meslek liselerinin orta kısımlarının açılmasının mümkün olmadığı için yalnızca imam-hatip liselerinin orta kısmı açılabileceğini belirtmektedir.

Genellikle öğretmenler özel okullara talebin arttığını ifade etmişlerdir. Ayrıca bu okullara bilinçli velilerin çocuklarını gönderdikleri, bu okullarda nitelikli eğitim olmadığı ve bu okulları iyi bir liseyi kazanamayanların tercih ettiklerini ifade ettikleri görülmektedir. Öğretmenlerin çoğunluğunun öğrenme ortamlarının teknolojik açıdan yeterli ve fiziki şartların yeterli olduğunu ifade ettikleri görülmektedir. Fakat bazı öğretmenlerin öğrenme ortamının olumsuz etkilendiğini, sınıflarda öğrenci sayısının arttığını ve fiziki şartların yetersiz olduğunu ifade ettikleri de görülmektedir. Öğrenci sayısının artması nedeni ile özellikle binası eski olan okullarda derslik ihtiyacı oluştuğu bilgisine ulaşılmıştır. Kütüphanenin sınıfa dönüştürüldüğü, etkinlikleri yapacak alanların kalmadığı ifade edilmiştir. Spor salonlarında ve toplantı salonlarında eksiklikler görülmüştür. Bütün bunların eğitimin kalitesini olumsuz etkilediği düşünülmektedir. Akkan (2013)'ın araştırmasında öğretmenler okulların vizyon, kültür ve fiziki durumlarının bu yeni sisteme uygun olmadığını belirtmişlerdir. Bu konuda kendilerini ikna edebilecek bilgi ve paylaşımların yetersiz olduğu görüşündedirler. Çapar (2015)'ın çalışmasında da öğretmenler, derslik ve binaların yetersiz olduğunu belirtmiştir. Kılınç (2014) okulların fiziksel altyapıları ve sistem değişikliğinden dolayı gerekli teknolojik donanıma sahip duruma getirilmesi gerektiğini belirtmiştir. Tok (2013)'un araştırmasında branş öğretmenlerinin çoğu yeni eğitim sistemine fiziki koşulların 
hazır olmadığını ifade etmiştir. Ortaöğretimin zorunlu olması aynı zamanda kaynak problemine yol açacaktır.

Bazı öğretmenler programın güncel olduğunu belirtmiştir. Başkaya (2016) araştırmasında kazanımların açıklanabilir ve uygulanabilir olduğunu, öğrencilerin hazırbulunuşluk düzeylerine uygun olduğunu belirtmiştir. Programın güncel olmadığını belirten öğretmen görüşleri de bulunmaktadır.

Öğretmenlerin bir kısmı farklı türden liselerde 9. sınıflarda uygulanan eğitim müfredatının aynı olmasının yanlış olduğunu belirtmiştir. Kılınç (2014) yeni sisteme uygun mevzuat değişikliklerinin yapılması gerektiğini belirtmiştir. Çamlıbel (2015)'in araştırmasında öğretmenler, programlar ve materyallerin okullara zamanında gelmediğini, uygulamadaki bu tür aksaklıkların eğitim-öğretimi olumsuz etkilediğini belirtmektedir.

Öğretmenlerin büyük kısmının ortaöğretime geçiş sürecinde bir sınavın olması gerektiğini ancak mevcut sınavın yeterince seçici olmadığını ifade ettiği görülmektedir. Çünkü ortaöğretime geçişin sınavla olmaması durumunda muhtemelen öğrencilerin ortaokuldaki ders notları ile ortaöğretime geçiş yapacakları düşünülmektedir. Fakat ortaokulda, notların abartılı verildiği ifade edildiği için adil bir liseye yerleştirme olmayacağı düşünülmektedir. Bu yüzden en iyi sistemin ülke şartlarında sınav olduğu belirtilmektedir. Öğretmenlerin, rehber öğretmenlerin öğrencileri mesleki gelişimleri açısından bilgilendirdikleri, okullarda kariyer günleri yapıldığını ifade ettikleri görülmektedir. Özellikle akademik başarısı yüksek olan birkaç okulda çeşitli meslek gruplarının öğrenciler ile bilgilendirme toplantıları yaptıkları görülmektedir.

Öğretmenlerin büyük kısmının ortaöğretimin zorunlu olmasının eğitimin niteliğini olumsuz yönde etkilediğini ifade ettikleri görülmüştür. Öğretmenlerin büyük kısmı lise öncesi ortaokulda notların abartılı olduğunu hatta özel okullarda, ortaokul ve liselerde notların abartılı olduğunu ifade etmiştir. Ayrıca öğretmenlerin önemli bir kısmının öğrencilerin liseye başladıklarında temel derslerde yetersiz olduğunu ifade ettikleri de görülmektedir.

Öğretmenlerden bazılarının ortaöğretim zorunlu olduktan sonra Türk Eğitim Sisteminde bir değişiklik olmadığını sadece okulların isimlerinin değiştiğini ifade ettikleri görülmektedir. Yapılan yorumlarda öğretmenle- 
rin sadece olumsuz görüş belirttikleri görülmüştür. Kılınç (2014) da araştırmasında yeni eğitim sisteminin Türk Eğitim Sisteminin amaç ve ilkelerine yeterince uymadığına ulaşmıştır.

Ortaöğretimin zorunlu olmasıyla ilgili olumlu görüşler incelendiğinde öğretmenlerin, çocukların okulda kontrol altında olduğunu ve kötü alışkanlıklardan korunduğunu ifade ettikleri görülmektedir. Çamlıbel (2015) araştırmasında, öğretmenlerin ve yöneticilerin hemen hemen tamamının 12 yıllık zorunlu eğitim uygulamasına ilişkin olumlu bakış açısına sahip olduğunu belirtmektedir. Ortaöğretimin zorunlu olmasının sağladığ olumsuz görüşler incelendiğinde öğretmenlerin, ara eleman eksikliği oluştuğunu, olumlu bir yönü olmadığını, işsizlik oranının arttığını ve öğrenci profilinin düştügünü ifade ettikleri görülmektedir.

Öğretmenlerin açı lise eğitimi hakkında olumlu görüş olarak açık lise eğitiminin gerekli olduğunu, örgün eğitime devamı engellemediğini, okumayanlar için ikinci fırsat olduğunu ve hem çalışıp hem okumanın mümkün olduğunu ifade ettikleri görülmektedir. Tok (2013)'un çalışmasında da bir kısım öğretmenler, ortaöğretimin açık öğretim ile tamamlanmasını olumlu bulmaktadır. Olumsuz olarak ise örgün eğitime devamı engelleyebileceğini ifade edenler olduğu görülmektedir. Çamlıbel (2015) araştırmasında açık lise ve açık ortaokul seçeneğinin kız çocuklarının aleyhine olarak okullaşmada sorunlar yaratacağı, bu uygulamanın çocuk işçiliği ve çocuk evliliklerinin önünü açacağı görüşlerini belirtmiştir.

Ortaöğretimin zorunlu öğretim kapsamına alınmasına ilişkin yönetici görüşleri incelendiğinde liselerin zorunlu olmasının doğru olduğunu, okullaşmanın düşük olduğu yerlerde faydalı olacağını, kızların erken evlendirilmesine ve okula gönderilmemelerine çözüm olacağını, çağdaş eğitim seviyelerine ulaşmak için gerekli olduğunu ifade edenler bulunmaktadır. Fakat okul yöneticilerinin bir kısmı ise zorunlu ortaöğretimin sanayide ara eleman eksikliği oluşturacağını, zorunlu olmasının doğru olmadığını, işsiz ve vasıfsız insan sayısında artış olacağını belirtmektedir. Bu bulguya benzer şekilde Tok (2013)'un çalışmasında da yöneticilerin büyük kısmı zorunlu ortaöğretimi olumsuz bulmuştur. Topdemir (2014)'in araştırmasında da yöneticilerin çoğunluğu 12 yıllık zorunlu eğitimi olumsuz bulmaktadır. 
Bazı okul yöneticileri ortaöğretim zorunlu yapılırken planlamanın yapıldığını, zorunlu ortaöğretimin devletin kalkınma planları arasında zaten olduğunu belirtmiştir. Fakat diğer yöneticilerimizden bunun tam tersini ifade edenler bulunmaktadır. Bazı yöneticilerimiz zorunlu ortaöğretime geçilirken planlamanın aceleyle yapıldığını, bazıları da planlamanın yapılmadığını belirtmektedirler. Topdemir (2014)'in araştırmasında da yöneticiler, yeni sistemin plansız ve hızlı bir şekilde hayata geçirildiğini ifade etmiştir. Bazı yöneticilerimizde zorunlu ortaöğretime bazı liseleri ön plana çıkarmak amacıyla geçildiğini ifade etmektedir. Ortaöğretimin zorunlu olmasından sonra geçiş süreci hakkında okul yöneticilerimizin herhangi bir olumlu görüş belirtmedikleri görülmüştür. Olumsuz görüş olarak ise zorunlu ortaöğretime geçerken geçiş sürecinin hızlı olduğunu, geçiş sürecinde aksaklıkların yaşandığını belirtenler bulunmaktadır. Benzer şekilde Başaran (2016)'ın araştırmasında da öğretmenler ve yöneticiler, sistem hakkında hem kendilerinin hem de velilerin yeteri kadar bilgilendirilmediklerini düşünmektedirler. Bazı okul yöneticilerimiz geçiş sürecinde altyapının hazırlanmadığını, bazı yöneticilerimiz okullarda öğretmen anlamında eksiklik ve fazlalık oluştuğunu belirtmişlerdir. Badur (2014)'un çalışmasında, 12 yıllık kesintisiz eğitime gerekli altyapı çalışmaları gerçekleştirilmeden geçildiği, bu nedenle de teknik ve fiziksel altyapı konusunda sorunlar yaşandığının belirlendiği ayrıca derslik sıkıntısı nedeniyle sınıf mevcutlarının arttığı sonucuna ulaşmış olması bu çalışmanın bulgularını destekler niteliktedir.

Hizmet içi eğitim açısından ise bazı yöneticilerimiz zorunlu ortaöğretime geçerken hizmet içi eğitim aldıklarını, bir yöneticimiz ise kendisinin inceleyerek öğrendiğini ifade etmektedirler. Fakat yöneticilerin büyük kısmı kendisinin zorunlu ortaöğretime geçilirken herhangi bir hizmet içi eğitim almadığını ifade etmektedir. Badur (2014)'un araştırmasında da eğitim sistemine öğretmenlerin uyum sağlaması açısından gerekli eğitim ve seminerler düzenlenmesi gerektiği görüşü ortaya çıkmıştır.

Ortaöğretimin zorunlu olması ile birlikte yöneticilerin birkaç tanesi Anadolu liselerinin başarısını koruduğunu, bir yöneticimiz ise genel liselerde bir problem olmadığını belirtmişlerdir. Fakat bazı yöneticilerimiz genel liselerde öğrenci profilinin değiştiğini, bazıları ise genel liselerde öğrenci sayısının arttığını ifade etmişlerdir. 
Yöneticiler ortaöğretimin zorunlu olmasından sonra meslek liselerinin isminin başına Teknik Anadolu getirildiğini ve bölge şartlarına göre alanlarda değişiklik yapılabildiğini ifade etmektedir. Zorunlu ortaöğretimden sonra meslek liselerine hiçbir okulu kazanamayan öğrencilerin geldiğini, bu okullarda disiplin sorunlarının oluştuğunu, bu okullara bilinçli olarak gelinmediği ve isminin başında yer alan Anadolu ibaresinden dolayı Anadolu lisesi sanıp gelenlerin olduğu şeklinde görüşler de ifade edilmiştir. Badur (2014) araştırmasında, 12 yıllık zorunlu eğitim sisteminde okul yönetiminde karşılaşılan sorunların daha fazla olduğu ve olumsuz davranış sergileyen öğrenci sayısında artış yaşandığı görüşünü belirtmiştir.

Yöneticiler, ortaöğretim zorunlu olduktan sonra özel okullarda öğrenci sayısının arttığını, özel liselerin Temel lise, Anadolu lisesi ve Fen lisesi isimlerini aldıklarını, özel okul sayısının arttığını, devletin üzerindeki yükü azaltacaklarını ve seviyesi düşük ama durumu iyi olan çocukların buraya yönlendirildiğini ifade etmiştir. Fakat bazı yöneticilerimiz ise özel liselerin haksız rekabete yol açtığını, bu okullarda devamsızlığa müsaade edildiğini ve notların şişirildiğini belirtmektedir. Ayrıca bu okulların dershane kültürü ile okul kültürü arasında bocaladıkları ifade edilmektedir.

Yöneticilerin büyük kısmı ortaöğretim zorunlu olduktan sonra okullarının teknolojik altyapı olarak yeterli olduğunu ifade etmektedirler. Okul binasının ve dersliklerin yeterli olduğu ve birkaç okulun oyun alanının olduğu şeklinde görüşlere ulaşılmıştır. Fakat bazı okul yöneticilerimiz ise zorunlu ortaöğretime geçildikten sonra okullarında sosyal alanları kapattıklarını, okullarının kapasitesinin yetmediğini, okullarında spor salonu olmadığını, okullarda öğrenci sayısının arttığını ve bazı okulların eğitim öğretime uygun olmadığını ifade etmişlerdir. Başaran (2016) da araştırmasında yeni sistemle birlikte eğitim ortamlarında (okul binası, derslik) fiziki yetersizlik oluştuğu ve sistemin uygulanmasında kalabalık sınıf ortamlarının sıkıntı yarattığı görüşüne ulaşmıştır. Çamlıbel (2015) de çalışmasında 12 yıllık zorunlu eğitim uygulamasından önce okulların fiziksel açıdan hazır olmadığını, mevcut fiziksel koşulların yaş gruplarına uygun olmadığını, okulda derslikler dışında kullanılan laboratuar, BİT laboratuarları gibi birimlerin de sınıflara dönüştürüldüğünü ve bu durumun da okulların fiziksel durumunu olumsuz olarak etkilediğini ifade etmektedir. 
Yine Topdemir (2014) de araştırmasında 12 yıllık zorunlu eğitim sonrası fiziki donanım ve altyapı yetersizliğine dair görüşlere ulaşmıştır.

Genellikle yöneticiler ortaöğretimin zorunlu olması ile birlikte eğitim programında değişikliğe gidildiği görüşünü ifade etmiştir. Ayrıca yeni bir programın tasarlanma aşamasında olduğu belirtilmektedir. Bazı yöneticilerimiz ise zorunlu ortaöğretime geçilirken, eğitim programında değişiklik olmadığını, eğitim programında değişikliğin olduğu fakat yeterli olmadığını, bütün liselerde aynı müfredatın olmasının yanlış olduğunu ve yapılan değişikliklerin ihtiyaca yönelik olmadığını belirtmişlerdir. Tok (2013)'un çalışmasında da yöneticiler, yeni eğitim sistemini eğitim programları açısından olumsuz bulmuştur.

Ortaöğretime geçiş sistemi hakkında yöneticilerimizin çoğunluğu liseye geçiş aşamasında sınav olması gerektiğini belirtmektedir. Bazı yöneticilerimiz ise eğer sınav olmazsa, bir kriterin bulunması gerektiğini ifade etmektedirler. Yöneticilerin, rehber öğretmenlerin öğrencileri mesleki gelişimleri açısından bilgilendirdiklerini, okullarda kariyer günleri yapıldığını ifade ettikleri görülmektedir.

Yöneticiler, zorunlu ortaöğretime geçildikten sonra eğitimin niteliğinin olumsuz etkilendiğini belirtmişlerdir. Ayrıca zorunlu ortaöğretime geçildikten sonra lisede okuma bilmeyen öğrencilerin oluştuğu, sınıf geçme sisteminin de eğitimi olumsuz etkilediği, sınıflarda ilgisiz öğrencilerin arttığ gibi görüşlere ulaşılmıştır. Birkaç yöneticimiz ise zorunlu ortaöğretime geçildikten sonra eğitimin kalitesinin olumsuz etkilenmediğini ifade etmektedirler. Başaran (2016)'ın araştırmasında ise yöneticiler yeni sistemin öğrencileri için atılmış olumlu bir adım olduğunu düşünmektedir.

Ortaokuldaki akademik başarının liseye yansıması açısından herhangi bir olumlu görüş bulunmamaktadır. Olumsuz görüş olarak ise ortaokulda notların abartılı olduğu, gerçeği yansıtmadığı, velilerin düşük nota itiraz ettiği ve özel okullarda daha fazla şişirme notlar verildiği görüşleri belirtilmiştir.

Temel dersler açısından okul yöneticilerimizden sadece 1 kişi öğrencilerin Lise 1'de yeterli olduğunu ifade etmektedir. Fakat yöneticilerin büyük kısmı ise öğrencilerin Lise 1'de yetersiz olduklarını belirtmişlerdir. Ayrıca zorunlu ortaöğretime geçildikten sonra meslek liseleri öğrencilerinin daha fazla yetersiz olduğu, devamsızlık ve sınıf tekrarı sorununun olduğu görüşleri ifade edilmektedir. 
Ortaöğretimin zorunlu olması ile birlikte Türk Eğitim Sistemi açısından bazı yöneticilerimiz bütün liselerin Anadolu Lisesi olduğunu, okulların kapasitesinin artııldı ğını ve kız öğrenci sayısının arttığını ifade etmektedirler. Fakat bazı yöneticilerimiz ise zorunlu ortaöğretime geçilirken eğitim sisteminde herhangi bir değişiklik olmadığını belirtmişlerdir. Okul yöneticilerinin ortaöğretimin zorunlu eğitim kapsamına alınması ile beraber Türk eğitim sisteminde hangi değişiklikler olduğuna yönelik yeterince bilgi sahibi olmadıkları görülmüştür.

Ortaöğretimin zorunlu olmasının sağladığı olumlu görüşler incelendiğinde yöneticiler zorunlu ortaöğretime geçildikten sonra üniversite ve öğrenci sayısının arttığı, kırsaldaki çocukların okula kazandırıldığı, zorunlu ortaöğretimin olumsuz bir özelliği olmadığı şeklinde görüşleri ifade etmişlerdir. Fakat zorunlu ortaöğretime geçildikten sonra ara eleman sıkıntısı oluştuğu, fiziksel ortamın olumsuz etkilendiği, eğitimin kalitesinin olumsuz etkilendiği, kırsaldan şehre insanların göç ettiği, vasıfsız insanların oluştuğu, çocukların zorla okula getirildiği ve devamsızlık sorunu oluştuğuna dair görüşlere de ulaşılmıştır. Çamlıbel (2015)'in çalışmasında da okul müdürü ve öğretmenlerin büyük bölümü, bir yeni sisteme geçişin plansız ve hızlı olmasının olumlu olmadığını, geçmişte yapılan bütün planlamaların boşa gittiğini, okulların mevcut değişime hazır olmadığını ve önlerini göremediklerini ifade etmiştir.

Açık lise eğitimi hakkında görüşler incelendiğinde yöneticilerimiz açık lise eğitiminin gerekli olduğunu, açı lisenin zamanında okumayanlar için firsat olduğunu, açık lise eğitim sisteminin olumlu olduğunu, açık lise eğitiminde mesleki derslerin yüz yüze verildiğini ve açık lisenin örgün eğitime devamı engellemediği görüşlerini ifade etmektedirler. Bazı yöneticilerimizin ise açık lise eğitiminin örgün eğitimin yerini tutmayacağı, açık lisenin örgün eğitimden kaçş̧ yolu olabileceği, açı lise eğitimine örgün eğitimde problem yaşanan öğrencilerin yönlendirilebileceği, açı lisenin örgün eğitime devamı engelleyebileceği ve açık lise sistemini olumsuz buldukları görülmüştür.

$\mathrm{Bu}$ araştırmada elde edilen bulgular doğrultusunda, eğitim sisteminde değişiklik yaparken, gerekli fiziksel ve teknolojik altyapı olmadan değişiklik yapılmaması, geçiş sürecinin çok kısa tutulmaması, öğretmenlere ve okul müdürlerine değişikliklerle ilgili yeterli bilgi verilmesi ve bilimsel veriler dikkate alınarak değişiklik yapılması önerilmektedir. 
Fen liseleri ve Anadolu liselerini kazanamayan öğrencilerin bir kısmı meslek lisesi veya İmam-hatip lisesine gitmek istemediği için zorunlu olarak özel okula gitmektedir. Yeni Anadolu liselerinin açılması ya da Anadolu liselerindeki kontenjanların uygun şartlar altında artırılması, öğrenciler için olumlu katkı sağlayacaktır. Belli bir akademik başarının altında olup Anadolu liselerini kazanamayan ve meslek liselerine gitmek istemeyen öğrenciler için yeniden bazı merkezlerde genel liseler açılabilir. Fiziki şartların yetersiz olduğu ve sınıfların kalabalık olduğu okulları rahatlatacak yeni okul binaları yapılmalıdır. Eğitim programları öğrencinin ve çağın gereksinimlerine göre sürekli güncellenmelidir. Zorunlu ortaöğretim ile birlikte ara eleman eksikliği ve işsizlik oranının arttığı sonucuna ulaşılmıştır. Meslek liselerinde ve genel liselerde yönlendirmenin daha profesyonel bir şekilde yapılması gerekir. Açık lise eğitimini fırsat bilerek özellikle kırsal kesimde çocukların örgün eğitimden uzaklaştırılmasına izin verilmemelidir. 
EXTENDED ABSTRACT

\title{
The Views of Teachers and Principals on Reflections of 4+4+4 Education System on Secondary Education
}

\author{
* \\ Sinan Kayıp- Şefik Kartal \\ MONE-Tokat Gaziosmanpaşa University
}

The duration of compulsory education has been 12 years in Turkey since 2012. This 12-year-compulsory education is divided into three stages. The first stage is organized as 4-year primary school, the second stage is 4-year secondary school and the third stage is 4-year high school. Changes in the education system closely affect all children, all the country and the future of the country. It is thought that some positive and negative results have emerged after the changes made in the education system. Some research has been done after these changes but nearly all of them focused on primary and secondary schools such as the positive and negative aspects of starting primary school one year earlier and problems in separating primary and secondary school (problems related to buildings, teachers, etc.). However, it was seen that the studies on compulsory secondary education are less in number and inadequate. Since the views of stakeholders on compulsory secondary education is thought to be important, it was aimed to analyse stakeholder views on reflections of $4+4+4$ education system on secondary education in this study. In order to reach this general purpose, the following questions guided the study:

1. What are the opinions of teachers about the reflections of the $4+4$ +4 Education System on secondary education?

2. What are the opinions of school principals about the reflections of $4+4+4$ Education System on secondary education?

This research was conducted qualitatively and "interview method" was used in order to collect the required data. The research was carried out between February and June 2017. The population of the research was composed of teachers and principals who work in various high schools in Tokat in Turkey. The sample of the study was determined by using the maximum variation sampling method, which is one of the purposeful 
sampling methods. While determining the teachers and principals to conduct the study with, it was paid attention to include teachers and principals who work in different types of high schools in different districts of Tokat in Turkey and thus, the sample of the study consisted of 15 teachers and 15 principals.

Two separate semi-structured interview forms were prepared for teachers and principals as the data collection tools. The interviews were recorded with a voice recorder with the permission of the interviewee, and transcribed. Interviews took an average of 25 minutes to complete. Descriptive analysis was used in the analysis of the data obtained in this research. The data obtained were described according to the themes posed by the questions asked in the interview (Yıldırım and Şimşek, 2013, s.258). Direct quotations were included in order to convey the opinions of the interviewees appropriately. When the opinions of the teachers and principals regarding incorporating secondary education within compulsory education were examined, it was seen that their opinions were similar and there were both positive and negative opinions. There was only one teacher stating that planning was done before incorporating secondary education within compulsory education, but the rest of the teachers stated that no planning was done. On the other hand, some principals indicated that planning was done while the others said it was not. Some of the teachers and principals said that transition process was too fast, and they generally indicated that they did not have in-service training on compulsory secondary education. It is thought that in-service training of teachers and principals about the new system is important since they are the practitioners of it and it is essential for them to grasp the aims of the new system to be implemented successfully.

It was generally pointed out that because of the compulsory secondary education, general high schools and vocational high schools were negatively affected, behaviour problems increased, and the success of the students decreased in these schools. They added that there were even illiterate students in these schools. The teachers and principals generally stated that the demand for private schools increased. Some of the principals added that private high schools caused unfair competition among the students, student absenteeism was allowed, and grades were inflated in these schools. 
It was seen that the physical conditions were sufficient and learning environments were technologically sufficient according to most of the teachers and principals. However, it was also observed that some teachers and principals were not agree with the others because they stated that due to the increase in the number of students in classes, there were needs for new classrooms especially in old school buildings. Some of the teachers and principals said that the curricula were up-to-date while the others said they were not. According to some principals it was wrong to have the same curricula in all types of high schools. Some of the teachers and principals were agree that compulsory secondary education caused the lack of intermediate staff in the industry.

Some of the teachers and principals expressed that children were under control and protected from bad habits, the children in rural areas continued their education and the number of female students increased thanks to the compulsory secondary education. On the other hand, they indicated that open high school was necessary, it did not prevent the continuation of formal education, it was the second opportunity for those who could not attend a school before, and it was possible for the students of open school to study and work at the same time. Contrary to this, some of the teachers and principals stated that it would prevent the continuation of formal education and it would not replace formal education.

While making changes in education systems, not making changes without necessary physical and technological infrastructure, not keeping the transition process too short, giving information to the teachers and principals about the changes and making changes in education system considering scientific data is suggested. General high schools should be opened for students who could not achieve a certain academic success, who could not go to Anatolian high schools and do not want to go to vocational high schools. New schools should be built to relieve schools where physical conditions are inadequate, and classes are crowded.

Curricula should be constantly updated according to the needs of the students and the era. It was stated that compulsory secondary education caused a shortage of intermediate staff in the industry. The guidance should be done in a more professional way in vocational high schools and general high schools. The students should not be allowed to leave school 
by taking the advantage of open high school education especially in rural areas.

\section{Kaynakça / References}

Ada, Ş. ve Küçükali, R. (2009). Türk Ĕ̆itim Sistemi ve okul yönetimi. Ankara: Anı Yayıncilik.

Akkan, E. (2013). 4+4+4 Eğitim Modelinin değişim yönetimi bakımından incelenmesi. (Yayımlanmamış yüksek lisans tezi). Uşak Üniversitesi, Sosyal Bilimler Enstitüsü, Uşak.

Badur, S. (2014). 12 yıllık zorunlu eğitim sisteminde okul yönetiminde karşılaşılan sorunlar. (Yayımlanmamış yüksek lisans tezi). Zirve Üniversitesi, Sosyal Bilimler Enstitüsü, Gaziantep.

Başaran, B. P. (2016). 4+4+4 Ĕ̈itim sisteminde yöneticilerin ve öğretmenlerin karşılaştığı sorunlar. (Yayımlanmamış yüksek lisans tezi). Gazi Üniversitesi Eğitim Bilimleri Enstitüsü, Ankara.

Başaran, İ. ve Çınkır, Ş. (2011). Türk eğitim sistemi ve okul yönetimi. Ankara: Ekinoks Yayıncilik.

Başkaya, A. (2016). 4+4+4 Eğitim sistemi ile yeniden düzenlenen ortaokul matematik programı hakkında öğretmen görüşleri. (Yayımlanmamış yüksek lisans tezi). Mersin Üniversitesi, Eğitim Bilimleri Enstitüsü, Mersin.

Çamlıbel, F. (2015). Okul müdürü ve öğretmenlerin 12 yıllık zorunlu eğitim uygulamasına ilişkin algıları. (Yayımlanmamış yüksek lisans tezi). Okan Üniversitesi, Sosyal Bilimler Enstitüsü, İstanbul.

Çapar, M. (2015). 12 yll zorunlu eğitim düzenlemesine dair öğretmen ve öğrenci algısl. (Yayımlanmamış yüksek lisans tezi). İstanbul Sabahattin Zaim Üniversitesi, Sosyal Bilimler Enstitüsü, İstanbul.

Demir, S. B., Doğan, S. ve Pınar, M. A. (2013). 4+4+4 Yeni eğitim sisteminin görüşleri yansımaları: Beşinci sınıflardaki eğitim öğretim sürecinin branş öğretmenlerinin doğrultusunda değerlendirilmesi. Turkish Studies, 8(9), 1081-1098.

Ercan, H. (2016). İlköğretim öğretmenlerinin ve yöneticilerinin 4+4+4 eğitim sisteminin uygulama sürecine ilişkin görüşleri. (Yayımlanmamış yüksek lisans tezi). Gaziosmanpaşa Üniversitesi, Eğitim Bilimleri Enstitüsü, Tokat.

Erginer, A. (2004). Türkiye' de on iki ylllı zorunlu eğitim için bir model önerisi ve uygulanabilirliği. (Yayımlanmamış doktora tezi). Ankara Üniversitesi, Eğitim Bilimleri Enstitüsü, Ankara. 
Ergün, M. (2003). Türkiye eğitiminde ortaöğretim reformu. İstanbul: Kültür Üniversitesi Yayınları.

Güven, İ. (2012). Eğitimde $4+4+4$ ve fatih projesi yasa tasarısı = reform mu? $\dot{I}$ kögrretim Online, 11(3), 556-577.

Kılınç, M. (2014). Eğitim sistemindeki değişimlerden 4+4+4 eğitim modeline ilişkin öğretmen görüşlerinin incelenmesi. (Yayımlanmamış yüksek lisans tezi). İstanbul Sabahattin Zaim Üniversitesi, Sosyal Bilimler Enstitüsü, İstanbul.

Milli Eğitim Temel Kanunu (24.06.1973). Sayı:14574

Senemoğlu, N. (2011). Gelişim, öğrenme ve öğretim. Ankara: Pegem Akademi Yayincilik.

Sönmez, V. ve Alacapınar G. F. (2013). Örneklendirilmiş bilimsel araştırma yöntemleri. Ankara: Anı Yayıncilık.

Sümbül, A. M. (2008). Ĕ̆itime yeni bakışlar. Ankara: Eğitim Akademi.

Şişman, M.(2012). Türk eğitim sistemi ve okul yönetimi. Ankara: Pegem Akademi. Tok, F. (2013). 12 yıllık zorunlu eğitim uygulamasına ilişkin öğretmen, yönetici ve veli görüşlerinin incelenmesi (Gaziantep Il Örneği) (Yayımlanmamış yüksek lisans tezi). Zirve Üniversitesi, Sosyal Bilimler Enstitüsü, Gaziantep.

Topdemir, S. (2014). 4+4+4 uygulamasının okul yöneticilerinin görüşlerine göre değerlendirilmesi (Diyarbakır İl Örneği) (Yayımlanmamış yüksek lisans tezi). Zirve Üniversitesi Sosyal Bilimler Enstitüsü, Gaziantep.

Türer, A. (2009). Ĕ̆itim bilimine giriş. Ankara: Detay Yayıncılık.

Türer, A. (2011). Türk eğitim tarihi. Ankara: Detay Yayıncılık.

Yıldırım, A. ve Şimşek, H. (2013). Sosyal bilimlerde nitel araştırma yöntemleri. Genişletilmiş 9. Baskı. Ankara: Seçkin Yayıncılık.

\section{Kaynakça Bilgisi / Citation Information}

Kayıp, S. ve Kartal, Ş. (2021). 4+4+4 Ĕ̆itim Sisteminin ortaöğretime yansımalarına ilişkin öğretmen ve yönetici görüşleri. OPUSUluslararası Toplum Araştırmaları Dergisi, 18(Eğitim Bilimleri Özel Say1s1), 4774-4823. DOI: 10.26466/opus.909516. 